\title{
Phytochemical profile and antiproliferative effect of Ficus crocata extracts on triple- negative breast cancer cells
}

Carlos A. Sánchez-Valdeolívar ${ }^{1 \dagger}$, Patricia Alvarez-Fitz ${ }^{2 \dagger}$, Ana E. Zacapala-Gómez ${ }^{1}$, Macdiel Acevedo-Quiroz ${ }^{3}$, Lorena Cayetano-Salazar ${ }^{1}$, Monserrat Olea-Flores' ${ }^{1}$, Jhonathan U. Castillo-Reyes ${ }^{1}$, Napoleón Navarro-Tito ${ }^{1}$, Carlos Ortuño-Pineda ${ }^{1}$, Marco A. Leyva-Vázquez ${ }^{1}$, Julio Ortíz-Ortíz ${ }^{1}$, Yaneth Castro-Coronel ${ }^{1}$ and Miguel A. Mendoza-Catalán ${ }^{1 *}$ (1)

\begin{abstract}
Background: Some species of the Ficus genus show pharmacological activity, including antiproliferative activity, in cell lines of several cancer Types. ficus crocata is distributed in Mexico and used in traditional medicine, as it is believed to possess anti-inflammatory, analgesic, and antioxidant properties. However, as of yet, there are no scientific reports on its biological activity. This study aims to evaluate the phytochemical profile of $F$. crocata leaf extracts and their effects on breast cancer MDA-MB-231 cells proliferation. Moreover, the study aims to unearth possible mechanisms involved in the decrease of cell proliferation.

Methods: The extracts were obtained by the maceration of leaves with the solvents hexane, dichloromethane, and acetone. The phytochemical profile of the extracts was determined using gas chromatography coupled with mass analysis. Cell proliferation, apoptosis, and cell cycle analysis in MDA-MB-231 cells were determined using a Crystal violet assay, MTT assay, and Annexin-V/PI assay using flow cytometry. The data were analyzed using ANOVA and Dunnett's test.

Results: The hexane (Hex-EFc), dichloromethane (Dic-EFc), and acetone (Ace-EFc) extracts of F. crocata decreased the proliferation of MDA-MB-231 cells, with Dic-EFc having the strongest effect. Dic-EFc was fractioned and its antiproliferative activity was potentiated, which enhanced its ability to induce apoptosis in MDA-MB-231 cells, as well as increased p53, procaspase-8, and procaspase-3 expression.
\end{abstract}

Conclusions: This study provides information on the biological activity of $F$. crocata extracts and suggests their potential use against triple-negative breast cancer.

Keywords: Ficus crocata, Moraceae, Breast cancer, Apoptosis, MDA-MB-231 cells

\footnotetext{
* Correspondence: mamendoza@uagro.mx

${ }^{\dagger}$ Carlos A. Sánchez-Valdeolívar and Patricia Alvarez-Fitz contributed equally to

this work.

'Facultad de Ciencias Químico Biológicas, Universidad Autónoma de

Guerrero, Av. Lázaro Cárdenas, Ciudad Universitaria, 39090 Chilpancingo,

Guerrero, Mexico

Full list of author information is available at the end of the article
}

(c) The Author(s). 2020 Open Access This article is licensed under a Creative Commons Attribution 4.0 International License, which permits use, sharing, adaptation, distribution and reproduction in any medium or format, as long as you give appropriate credit to the original author(s) and the source, provide a link to the Creative Commons licence, and indicate if changes were made. The images or other third party material in this article are included in the article's Creative Commons licence, unless indicated otherwise in a credit line to the material. If material is not included in the article's Creative Commons licence and your intended use is not permitted by statutory regulation or exceeds the permitted use, you will need to obtain permission directly from the copyright holder. To view a copy of this licence, visit http://creativecommons.org/licenses/by/4.0/ The Creative Commons Public Domain Dedication waiver (http://creativecommons.org/publicdomain/zero/1.0/) applies to the data made available in this article, unless otherwise stated in a credit line to the data. 


\section{Background}

Breast cancer is the most common cancer and the main cause of death for women worldwide. It represents about $12 \%$ of all new cancer cases and $25 \%$ of all cancers in women [1]. Triple-negative breast cancer (TNBC) represents $10-20 \%$ of all breast carcinomas [2] and is characterized by no expression of estrogen receptors (ER) and progesterone receptors $(\mathrm{PR})$, and the lack of overexpression of the HER2 protein. Thus, the tumoral cells do not respond to hormone therapy, and it is considered the subtype with the worst prognosis among breast cancer cases [3-5]. Among the different drugs used in cancer, many of these are derived from plants and some are utilized in their natural form or with structural modifications, such as polyphenols (e.g., resveratrol [6], epicathechin [7], and epigallocatechin gallate [8]) and flavonoids (e.g., quercetin [9], silibinin [10], and oncamex [11]), which, in cancer cells, have demonstrated the ability to induce apoptosis [12-15].

Ficus genus species are employed in traditional medicine for the treatment of asthma, migraine, cough, diarrhea, earache, toothache, scabies, and eye problems [1621]. Several studies have reported that some species of Ficus possess pharmacological activities, such as antioxidant [20, 22-26], antimicrobial [26-29], antiviral [30$32]$, anti-inflammatory [33-36], antiparasitic [20, 37], antidiabetic [25, 38-42], antiproliferative [28, 43-53], and cytotoxic activities [32, 53-57]. Extracts of Ficus religiosa have exhibited cytotoxic properties, inducing apoptosis in cervical cancer HeLa cell lines and cell cycle arrest in SiHa cells [45]. Moreover, Ficus fistulosa, Ficus hispida, and Ficus schwarzii have shown antiproliferative activity in human brain glioblastoma (U87MG), lung adenocarcinoma (A549), and colorectal adenocarcinoma (HT-29) cell lines [43]. The biological properties of Ficus species are attributed to the wide range of secondary metabolites identified in the root, stem, leaf, bark, and fruit, which are mostly alkaloids, flavonoids, coumarins, phenols, steroids, terpenoids, and triterpenoids $[9,16,18,21,23-26$, 39, 40, 51, 52, 54, 56, 58, 59]. In Mexico, the presence of 21-40 species of Ficus has been reported, among which 13 species have been identified in southern Mexico, including Ficus crocata [60-62]. However, there are no reports on the biological activity of these species of Ficus. This study aimed to evaluate the phytochemical profile of leaf extracts of F. crocata and the effect of the exposure of breast cancer cells MDA-MB-231 to these extracts. Moreover, cell proliferation and the possible mechanisms involved in the decrease of proliferation, such as apoptosis and cell cycle arrest, were investigated.

\section{Methods}

\section{Plant material}

Leaves of F. crocata were collected from the wild in Petaquillas, Guerrero State, Mexico (latitude: 17.3708, longitude: - 99.5344, altitude: 1160 masl); in accord with Mexican official standard NOM-059-SEMARNAT-2010, there are no restrictions for the collection of this species. The plant was authenticated by Blanca Verónica JuárezJaime, M.Sc., and Mauricio Mora-Jarvio, B. Sc, biologists from Herbario Nacional de México (MEXU). A voucher specimen (MEXU-2052) was deposited at the same institute.

\section{Preparation of extracts and fractionation}

Leaves of F. crocata (100 g) were dried and ground, and then successively macerated (sequential extraction) with hexane, dichloromethane, and acetone solvents (reactive-grade, $500 \mathrm{~mL}$ during $24 \mathrm{~h}$, three times). The macerated material was filtered, and the organic phase was evaporated in a rotary evaporator (Digital Rotary Evaporator Model 410$)$ at $60{ }^{\circ} \mathrm{C}$ and $80 \mathrm{rpm}$. Hexane $(1.51 \%$ yield; Hex-EFc), and dichloromethane (0.94\% yield; DicEFc), and acetone (11.75\% yield; Ace-EFc) extracts were stored at $-20{ }^{\circ} \mathrm{C}$ and protected from light.

Dic-EFc was subjected to fractionation by Open glass Column Chromatography (OCC, ID: $20 \mathrm{~mm}$ ) packed with $30 \mathrm{~g}$ of silica gel (7734, $60 \AA$, 70-230 mesh; SigmaAldrich). The procedure was initiated with the hexaneacetone 9:1 elution system and the polarities were gradually increased with acetone until finally obtaining 149 aliquots $(10 \mathrm{~mL})$. Aliquots were analyzed by TLC (silica gel $60, \mathrm{~F}_{254}, 20 \times 20 \mathrm{~cm}$; Merck, Germany) and visualized by UV light at 254 and $365 \mathrm{~nm}$ and were combined according to the characteristics observed by TLC in 17 fractions (A1/A17-Dic-EFc). The fractions were monitored by thin layer chromatography (TLC) (Silica gel 60 F254; Merck, Germany) and visualized by ultraviolet (UV) light at $254 \mathrm{~nm}$, then revealed with vanillin-sulfuric acid, vanillin-phosphoric acid, Dragendorff reagent, Liebermann-Burchard reagent, potassium hydroxide reagent $(\mathrm{KOH})$, and acid developer [63].

\section{Gas chromatography coupled with mass analysis (GC-MS)} GC-MS analyses were carried in triplicate out on an Agilent 6890 series gas chromatograph equipped with a mass selective detector $5973 \mathrm{~N}$ (USA). The experimental conditions of GC-MS system were as follows [64]: HP-5MS capillary nonpolar column (30 m, ID: $0.20 \mathrm{~mm}$, film thickness: $0.25 \mu \mathrm{m}$ ). The carrier gas was helium at flow rate of $1.0 \mathrm{~mL} / \mathrm{min}$. In the gas chromatography part, the temperature program (oven temperature) was $50{ }^{\circ} \mathrm{C}$ raised to $230{ }^{\circ} \mathrm{C}$ at $2{ }^{\circ} \mathrm{C} / \mathrm{min}$ and the injection volume was $1 \mu \mathrm{L}$. Samples were dissolved in dichloromethane. All results were compared by using NIST/EPA/NIH Mass Spectral library version $1.7 \mathrm{a} /$ ChemStation. 


\section{Cell culture and exposure to extracts}

MDA-MB-231 cells (ATCC ${ }^{\bullet} \mathrm{HTB}^{26}$ ) were cultured in Dulbecco's Modified Eagle Medium Formula 12 (DMEM/F12) supplemented with 5\% Fetal Bovine Serum (FBS), 1\% antibiotic (ampicillin/streptomycin), and incubated at $37{ }^{\circ} \mathrm{C}$ in a $5 \% \mathrm{CO}_{2}$ atmosphere and at $95 \% \mathrm{hu}-$ midity. Cells were synchronized with basal medium without FBS for $24 \mathrm{~h}$ and exposed to $0-80 \mu \mathrm{g} \mathrm{mL}^{-1}$ of $F$. crocata extracts for 24-48 h. DiMethyl SulfOxide (DMSO) was used as the diluent of extracts (Vehicle). As a positive control, cells were treated with $100 \mu \mathrm{M}$ Cytarabine (Ara-C), which is known to induce cell death [65]. As a negative control, cells were treated with 5\% FBS to induce cell proliferation. All tests were performed in triplicate at three independent times.

\section{Cell growth in monolayer (crystal violet assay)}

A total of $15 \times 10^{3}$ cells were plated on 24-well plates (Corning) and cultured in DMEM/F12 medium supplemented with 5\% FBS for $24 \mathrm{~h}$. Cells were treated with $0,5,10,20,40$, and $80 \mu \mathrm{g} \mathrm{mL}^{-1}$ of F. crocata extracts for 24 and $48 \mathrm{~h}$, fixed after treatment in $4 \%$ formaldehyde for $5 \mathrm{~min}$, and the cell morphology was observed using an inverted microscope (EVOS Cell Imaging System; Thermo Scientific). Later, the cells were stained with $0.5 \%$ Crystal violet, the excess dye was washed with water and PBS (Phosphate-Buffered Saline) and the stain was extracted with $10 \%$ acetic acid. The relative cell density in the monolayer was determined by measuring the optical density (OD) of each well at $600 \mathrm{~nm}$ in a biophotometer (Eppendorf Model RS-2312 DH $8.5 \mathrm{~mm})$.

\section{MTT assay}

The percentage of viable cells was evaluated using the MTT cell proliferation colorimetric assay (CT02, Millipore Corp., Bedford, MA, USA) according to the manufacturer's instructions. Briefly, in a 96-well plate, $1 \times 10^{4}$ MDA-MB-231 cells per well were cultured for $24 \mathrm{~h}$ with DMEM/F12 medium with 5\% FBS and subsequently with basal medium for $24 \mathrm{~h}$ to synchronize the cells in the G1 phase and promote a homogeneous cellular response. Then, the treatment with $0-80 \mu \mathrm{g} \mathrm{mL}^{-1}$ of $F$. crocata extracts or fractions was applied for 24 and $48 \mathrm{~h}$. After the treatment, the medium containing the extracts was replaced by fresh basal medium and $100 \mu \mathrm{L}$ of the MTT reagent was added for $4 \mathrm{~h}$. The formazan crystals were diluted with isopropanol, and the OD of the supernatant was obtained at a wavelength of $540 \mathrm{~nm}$ using a biophotometer (Eppendorf Model RS-2312 DH $8.5 \mathrm{~mm}$ ). The half-maximal inhibitory concentration $\left(\mathrm{IC}_{50}\right)$ was calculated through the linear eq. $(\mathrm{Y}=\mathrm{mX}+\mathrm{b})$ using GraphPad prism software v6.0.

\section{Analysis of apoptosis}

In order to determine the cell population in apoptosis after the treatment with F. crocata extracts, the Fluorescein Isothiocyanate (FITC) Annexin V Apoptosis Detection Kit I (556,547; Beckton Dickinson) was used according to the manufacturer's instructions. Briefly, MDA-MB-231 cells were seeded at a density of $2 \times 10^{5}$ cells/well in a six-well plate for $24 \mathrm{~h}$ with DMEM and $5 \%$ FBS. The cells were synchronized with basal medium for $24 \mathrm{~h}$ and subsequently exposed to Dic-EFc (0, 20, 40, and $80 \mu \mathrm{g} \mathrm{mL}^{-1}$ ) or A9, A12, and A13-Dic-EFc fractions $\left(80 \mu \mathrm{g} \mathrm{mL}^{-1}\right)$ for $48 \mathrm{~h}$. Cells were collected by trypsinization followed by washing with PBS, and staining with FITC Annexin V and propidium iodide (PI) for $15 \mathrm{~min}$ in the dark. They were then immediately analyzed by flow cytometry (FACSCanto II; Beckton Dickinson, USA). The FITC Annexin V- and PI-negative cells were considered viable cells. Cells in early apoptosis were FITC Annexin V-positive and PI-negative, while cells in late apoptosis were both FITC Annexin V- and PIpositive.

\section{Analysis of cell cycle arrest}

MDA-MB-231 cells were seeded at a density of $2 \times 10^{5}$ cells/well in a six-well plate and incubated for $24 \mathrm{~h}$ in an incubator at $37{ }^{\circ} \mathrm{C}$ with a $5 \% \mathrm{CO}_{2}$ atmosphere. The cells were synchronized in basal medium for $24 \mathrm{~h}$ and subsequently exposed to Dic-EFc $\left(0,20,40\right.$, and $\left.80 \mu \mathrm{g} \mathrm{mL}^{-1}\right)$ or A9, A12, and A13-Dic-EFc fractions $\left(80 \mu \mathrm{g} \mathrm{mL}^{-1}\right)$ for $48 \mathrm{~h}$. Cells were collected by trypsinization followed by washing with PBS, centrifugation, and fixing with ethanol. Subsequently, the cells were centrifuged and resuspended in cold PBS. A total of $20 \mu \mathrm{g} \mathrm{mL}^{-1}$ RNAsa was added for $30 \mathrm{~min}$ and, the cells were stained with Propidium Iodide (PI) in the dark at room temperature for 15 min. The immunofluorescence of PI was analyzed by flow cytometry (FACSCanto II; Beckton Dickinson).

\section{Immunobloting for p53 and caspases}

After cell stimulation with the Dic-EFc or A9- Dic-EFc fraction, the cells were solubilized in $0.2 \mathrm{~mL}$ of RIPA buffer (50 mM HEPES pH 7.4, $150 \mathrm{mM} \mathrm{NaCl}, 1 \mathrm{mM}$ EDTA/EGTA, $10 \mathrm{mM}$ sodium pyrophosphate, 10\% glycerol, 1\% Triton X-100, 1\% sodium deoxycholate, 1.5 $\mathrm{mM} \mathrm{MgCl}_{2}, 0.1 \%$ SDS, $100 \mathrm{mM} \mathrm{NaF}, 1 \mathrm{mM}$ sodium orthovanadate and $1 \mathrm{mM}$ PMSF). Whole cell lysates $(20 \mu \mathrm{g})$ were resolved on $10 \%$ SDS-polyacrylamide gels and transferred to nitrocellulose membranes. The membranes were incubated in 5\% non-fat dried milk in PBS for $1 \mathrm{~h}$ at room temperature (RT), and incubated with the primary antibodies anti-p53 (Sc-126, SC Biotech, 1: 2000 dilution), anti-caspase-3 (which also recognizes other caspases in according to cell type) ( $\mathrm{H}-277$, sc7148, 1:2000 dilution), and anti-GAPDH (AB clonal 
AC001, 1:5000 dilution) at $4{ }^{\circ} \mathrm{C}$ overnight. Later, the membranes were incubated for $2 \mathrm{~h}$ at RT with secondary anti-mouse or anti-rabbit (1:5000 dilution, MERCK Millipore), and revealed with a chemiluminescent substrate from Bio-Rad (Hercules, CA, USA).

\section{Statistical analysis}

Data analysis was performed using the GraphPad Prism version 7.0 statistical software. The data were shown as the mean \pm standard deviation (SD). One-way analysis of variance (ANOVA) was used with Dunnett's test. A statistically significant difference was considered when $p<0.05$.

\section{Results}

\section{Phytochemical analysis}

The GC-MS analysis of Hex-EFc, Dic-EFc and Ace-EFc extracts revelated the existence of 19, 10 and 6 phytochemical compounds, respectively (Table 1). The most prevailing compounds were the terpenes lup-20(29)-en3 -ol acetate $(28.39 \%)$ and lupeol (18.61\%) in Hex-EFc; lupeol (27.86\%), the fatty acid 10,13,13-trimethyl-11-tetradecen-1-ol acetate (14.80\%), and lup-20 (29)-en-3-ol acetate (10.90\%) in Dic-EFc; and $\beta$-sitosterol (42.36\%) and stigmastan-3,5-dien (23.87\%) in Ace-EFc. Compounds identification was established based on the peak area (\%), and retention time (RT) (Table 1). The chemical structures of the molecules identified are expressed in Figs. S1, S2, and S3.

\section{Leaf extracts of $F$. crocata decreased the proliferation of MDA-MB-231 cells}

To evaluate the antiproliferative activity of $F$. crocata extracts on MDA-MB-231 breast cancer cells, crystal violet and MTT assays were performed. It was observed that Hex-EFc, Dic-EFc, and Ace-EFc decreased the number of cells in the monolayer in a concentration- and timedependent manner. At $24 \mathrm{~h}$ of treatment, only 40 and $80 \mu \mathrm{g} \mathrm{mL}^{-1}$ concentrations decreased the cell density compared to the untreated control cells $(p<0.001)$. The effect of extracts was greater at $48 \mathrm{~h}$, showing a lower cell density in the monolayer at all of the tested concentrations and, decreasing the number of cells as the concentration increased $(p<0.001)$ (Fig. 1). In addition, Dic-EFc and Ace-EFc induced morphologic changes in MDA-MB231 cells, such as a decrease in cell size, a rounded shape, and the formation of intracellular vacuoles suggestive of apoptosis (Fig. 2). These cellular changes were evident at $48 \mathrm{~h}$ with $5-, 10-$, and $20-\mu \mathrm{gL}^{-1}$ concentrations, mainly with Dic-EFc. Figure 2 shows the effect of the extracts at $20 \mu \mathrm{g} \mathrm{mL}{ }^{-1}$ after $48 \mathrm{~h}$ of treatment.

In order to validate the data observed with the Crystal violet assay, the effect of the extracts on cell proliferation was determined by MTT assay in order to consider only metabolically viable cells. After $24 \mathrm{~h}$ of treatment, a significant decrease in cell proliferation was observed with $\geq 5 \mu \mathrm{g} \mathrm{mL}^{-1}$ of Dic-EFc, $\geq 10 \mu \mathrm{g} \mathrm{mL}^{-1}$ of Ace-EFc, and $\geq 20 \mu \mathrm{g} \mathrm{mL}^{-1}$ of Hex-EFc compared to untreated control cells. After prolonging exposure to extracts for $48 \mathrm{~h}, \mathrm{Hex}-\mathrm{EFc}$, Dic-EFc, and Ace-EFc decreased cell proliferation at all tested concentrations compared to control cells $(p<0.001)$. However, this effect was more evident with Dic-EFc, which decreased the percentage of viable cells by more than $50 \%$ with $10-80 \mu \mathrm{g} \mathrm{mL}^{-1}(p<$ 0.001 ) (Fig. 3). Antiproliferative activity at $48 \mathrm{~h}$ was greater for Dic-EFc $\left(\mathrm{IC}_{50}: 32.43 \mu \mathrm{g} \mathrm{mL}^{-1}\right.$ ), followed by Ace-EFc $\left(\mathrm{IC}_{50}: 78.49 \mu \mathrm{g} \mathrm{mL}{ }^{-1}\right)$, and Hex-EFc $\left(\mathrm{IC}_{50}\right.$ : $164.05 \mu \mathrm{g} \mathrm{mL}^{-1}$ ) (Fig. S4). In addition, the effect of DICEFc on viability of MCF-10A non-tumor cells was preliminary evaluated, and only $320 \mu \mathrm{g} \mathrm{mL}^{-1}$ of extract showed cytotoxic effect at $48 \mathrm{~h}$ of treatment (Fig. S5).

Considering that Dic-EFc exhibited the best effect in decreasing cell proliferation $\left(\mathrm{IC}_{50}: 32.43 \mu \mathrm{g} \mathrm{mL}^{-1}\right), 17$ fractions of Dic-EFc were obtained. The fractions demonstrated the presence of cardiotonic glycosides and anthraquinones (Table S1). Considering the phytochemical profile, three fractions (A9-Dic-EFc, A12-Dic-EFc, and A13-Dic-EFc) were selected to evaluate their effect on the proliferation of MDAMB-231 cells. The A9-Dic-EFc fraction exhibited the presence of anthraquinones, triterpenoids, lignans, essential oils, phenylpropanoids, cucurbitacins, steroids, and saponins. The A12-Dic-EFc fraction revealed only the presence of anthraquinones, while the A13-Dic-EFc fraction contained lignans, anthraquinones, and cardiotonic glucosides (Table S1). Exposure to $\geq 40 \mu \mathrm{g} \mathrm{mL}^{-1}$ of A9-Dic-EFc for $24 \mathrm{~h}$ decreased the number of viable cells by around $70 \%(p<0.001)$ and this effect was maintained at $48 \mathrm{~h}$ of exposure. On the other hand, after $24 \mathrm{~h}$ of exposure to $>40 \mu \mathrm{g} \mathrm{mL}^{-1}$ of A12-Dic-EFc, the cell proliferation was decreased by around $50 \%$, and $>20 \mu \mathrm{g}$ $\mathrm{mL}^{-1}$ of A13-Dic-EFc decreased cell proliferation by around $60 \%$. However, at $48 \mathrm{~h}$, both fractions maintained their antiproliferative activity at a concentration of only $80 \mu \mathrm{gL}^{-1}$ (Fig. 4). Low concentrations of the A9-Dic-EFc fraction (5$20 \mu \mathrm{g} \mathrm{mL}^{-1}$ ) exhibited no effect on the proliferation of MDA-MB-231 cells, while low concentrations of A-12- and A13-Dic-EFc fractions $\left(5-10 \mu \mathrm{g} \mathrm{mL}^{-1}\right)$ appeared to stimulate cell proliferation after $24 \mathrm{~h}$ (A12- and A13-Dec-EFc) or $48 \mathrm{~h}$ of exposure (A12-Dec-EFc) (Fig. $4 \mathrm{~b}$ and c). Considering the above, the A9-Dic-EFc fraction showed a better effect for decreasing cell proliferation and this observation could be explained by differences in the phytochemical profile of A9-Dic-EFc with respect to the A12- and A13-Dic-EFc fractions described previously (Table S1). Antiproliferative activity against MDA-MB-231 cells after $48 \mathrm{~h}$ of exposure was greatest for the A9-Dic-EFc fraction $\left(\mathrm{IC}_{50}\right.$ : $39.89 \mu \mathrm{g} \mathrm{mL}^{-1}$ ), followed by the A13-Dic-EFc fraction $\left(\mathrm{IC}_{50}: 80.49 \mu \mathrm{g} \mathrm{mL}^{-1}\right)$ and the A12-Dic-EFc fraction $\left(\mathrm{IC}_{50}: 126.76 \mu \mathrm{g} \mathrm{mL}^{-1}\right.$ ) (Fig. S4). 
Table 1 The chemical composition of extracts from F. crocata using GC-MS.

\begin{tabular}{|c|c|c|c|c|}
\hline Plant extract & Name of compound & Molecular formula & Molecular weight & Peak area \\
\hline Hex-EFc & & & $(\mathrm{g} / \mathrm{mol})$ & (\%) \\
\hline 1 & 3,7,11,15-tetramethyl-2,1-hexadecen 1-ol & $\mathrm{C}_{20} \mathrm{H}_{40} \mathrm{O}$ & 296.539 & 0.120 \\
\hline 2 & 2-pentadecanone,6,10,14-trimethyl- & $\mathrm{C}_{18} \mathrm{H}_{36} \mathrm{O}$ & 268.485 & 0.404 \\
\hline 3 & 1-dodecanol 3,7,11-trimethyl & $\mathrm{C}_{15} \mathrm{H}_{32} \mathrm{O}$ & 228.42 & 0.174 \\
\hline 4 & hexadecanoic acid, ethyl ester & $\mathrm{C}_{18} \mathrm{H}_{36} \mathrm{O}_{2}$ & 284.484 & 0.096 \\
\hline 5 & 4,8,12,16-tetramethyl-heptadecan-4-olide & $\mathrm{C}_{21} \mathrm{H}_{40} \mathrm{O}_{2}$ & 324.549 & 0.314 \\
\hline 6 & 2H-pyran-ona, tetrahydro-6-trydecyl & $\mathrm{C}_{18} \mathrm{H}_{34} \mathrm{O}_{2}$ & 282.468 & 1.470 \\
\hline 7 & octacosane & $\mathrm{C}_{28} \mathrm{H}_{58}$ & 394.772 & 8.697 \\
\hline 8 & hexatriacontane & $\mathrm{C}_{36} \mathrm{H}_{74}$ & 506.988 & 9.133 \\
\hline 9 & campesterol & $\mathrm{C}_{28} \mathrm{H}_{48} \mathrm{O}$ & 400.691 & 0.625 \\
\hline 10 & stigmasterol & $\mathrm{C}_{29} \mathrm{H}_{48} \mathrm{O}$ & 412.702 & 1.334 \\
\hline 11 & $\beta$-sitosterol & $\mathrm{C}_{29} \mathrm{H}_{50} \mathrm{O}$ & 414.718 & 5.288 \\
\hline 12 & 13,27-cycloursane & $\mathrm{C}_{30} \mathrm{H}_{50} \mathrm{O}$ & 410.718 & 1.874 \\
\hline 13 & a-amyrin & $\mathrm{C}_{30} \mathrm{H}_{50} \mathrm{O}$ & 426.729 & 1.308 \\
\hline 14 & lup-20 (29)-en-3-one & $\mathrm{C}_{30} \mathrm{H}_{48} \mathrm{O}$ & 424.713 & 4.665 \\
\hline 15 & lupeol & $\mathrm{C}_{30} \mathrm{H}_{50} \mathrm{O}$ & 426.729 & 18.610 \\
\hline 16 & 13,27-3-cycloursan-3-ol acetate, $(3 \beta, 13 \beta, 14 \beta)$ & $\mathrm{C}_{32} \mathrm{H}_{52} \mathrm{O}_{2}$ & 468.754 & 4.608 \\
\hline 17 & lup-20 (29)-en-3-ol, acetate (3ß) & $\mathrm{C}_{32} \mathrm{H}_{52} \mathrm{O}_{2}$ & 468.7541 & 28.386 \\
\hline 18 & friedelin & $\mathrm{C}_{30} \mathrm{H}_{50} \mathrm{O}$ & 426.729 & 4.335 \\
\hline 19 & 9,19-cyclolanostan-3-ol, 24, methylene, acetato, $(3 \beta)$ & $\mathrm{C}_{31} \mathrm{H}_{52} \mathrm{O}$ & 440.756 & 1.691 \\
\hline \multicolumn{5}{|l|}{ Dic-EFc } \\
\hline 1 & acetic acid, 2 (2,2,6 trimethyl-7-oxa-bicyclo-(4,10)-hept-1-yl propenyl ester & $\mathrm{C}_{14} \mathrm{H}_{22} \mathrm{O}_{3}$ & 238.323 & 5.748 \\
\hline 2 & 2-pentadecanone,6,10,14-trimethyl- & $\mathrm{C}_{18} \mathrm{H}_{36} \mathrm{O}$ & 268.485 & 6.994 \\
\hline 3 & 3,7,11,15-tetramethyl-2,1-hexadecen 1-ol & $\mathrm{C}_{20} \mathrm{H}_{40} \mathrm{O}$ & 296.539 & 4.174 \\
\hline 4 & 10,13,13-trimethyl-11-tetradecen-1-ol acetate & $\mathrm{C}_{19} \mathrm{H}_{36} \mathrm{O}_{2}$ & 296.495 & 14.808 \\
\hline 5 & octadecanal 2-bromo & $\mathrm{C}_{18} \mathrm{H}_{35} \mathrm{BrO}$ & 347.381 & 0.915 \\
\hline 6 & 4,25-secoobscurinervan, 21-deoxy-16methoxy-22-methyl-(22 a) & $\mathrm{C}_{23} \mathrm{H}_{22} \mathrm{~N}_{2} \mathrm{O}_{2}$ & 368.512 & 0.911 \\
\hline 7 & stigmasterol & $\mathrm{C}_{29} \mathrm{H}_{48} \mathrm{O}$ & 412.702 & 1.247 \\
\hline 8 & $\beta$-sitosterol & $\mathrm{C}_{29} \mathrm{H}_{50} \mathrm{O}$ & 414.718 & 5.121 \\
\hline 9 & lupeol & $\mathrm{C}_{30} \mathrm{H}_{50} \mathrm{O}$ & 426.729 & 27.861 \\
\hline 10 & lup-20 (29)-en-3-ol, acetate (3ß) & $\mathrm{C}_{32} \mathrm{H}_{52} \mathrm{O}_{2}$ & 468.7541 & 10.903 \\
\hline \multicolumn{5}{|l|}{ Ace-EFc } \\
\hline 1 & 3,7,11,15-tetramethyl-2,1-hexadecen 1-ol & $\mathrm{C}_{20} \mathrm{H}_{40} \mathrm{O}$ & 296.539 & 1.700 \\
\hline 2 & squalene & $\mathrm{C}_{30} \mathrm{H}_{50}$ & 410.73 & 0.547 \\
\hline 3 & stigmastan-3,5-dien & $\mathrm{C}_{29} \mathrm{H}_{48}$ & 396.703 & 23.877 \\
\hline 4 & alpha-tocopherol & $\mathrm{C}_{29} \mathrm{H}_{50} \mathrm{O}_{2}$ & 430.717 & 8.627 \\
\hline 5 & $\beta$-sitosterol & $\mathrm{C}_{29} \mathrm{H}_{50} \mathrm{O}$ & 414.718 & 42.363 \\
\hline 6 & lupeol & $\mathrm{C}_{30} \mathrm{H}_{50} \mathrm{O}$ & 426.729 & 6.961 \\
\hline
\end{tabular}

The dichloromethane extract of $F$. crocata induced apoptosis and cell cycle arrest in MDA-MB-231 cells

To determine possible mechanisms to reduce the proliferation of MDA-MB-231 cells exposed to the dichloromethane extract of $F$. crocata, an apoptosis assay and cell cycle analysis were performed. Only the concentrations of Dic-
EFc $\left(20-80 \mu \mathrm{g} \mathrm{mL}^{-1}\right)$ and its fractions $\left(80 \mu \mathrm{g} \mathrm{mL}^{-1}\right)$ that reduced around $50 \%$ or more of cell proliferation were analyzed. It was observed that the Dic-EFc treatment induced apoptosis in 4.3 and $7.7 \%$ of the cell population with $20 \mu \mathrm{g} \mathrm{mL}^{-1}$ and $40 \mu \mathrm{g} \mathrm{mL}^{-1}$, respectively, while $80 \mu \mathrm{g} \mathrm{mL}^{-1}$ increased the apoptotic population to $19.3 \%$ 

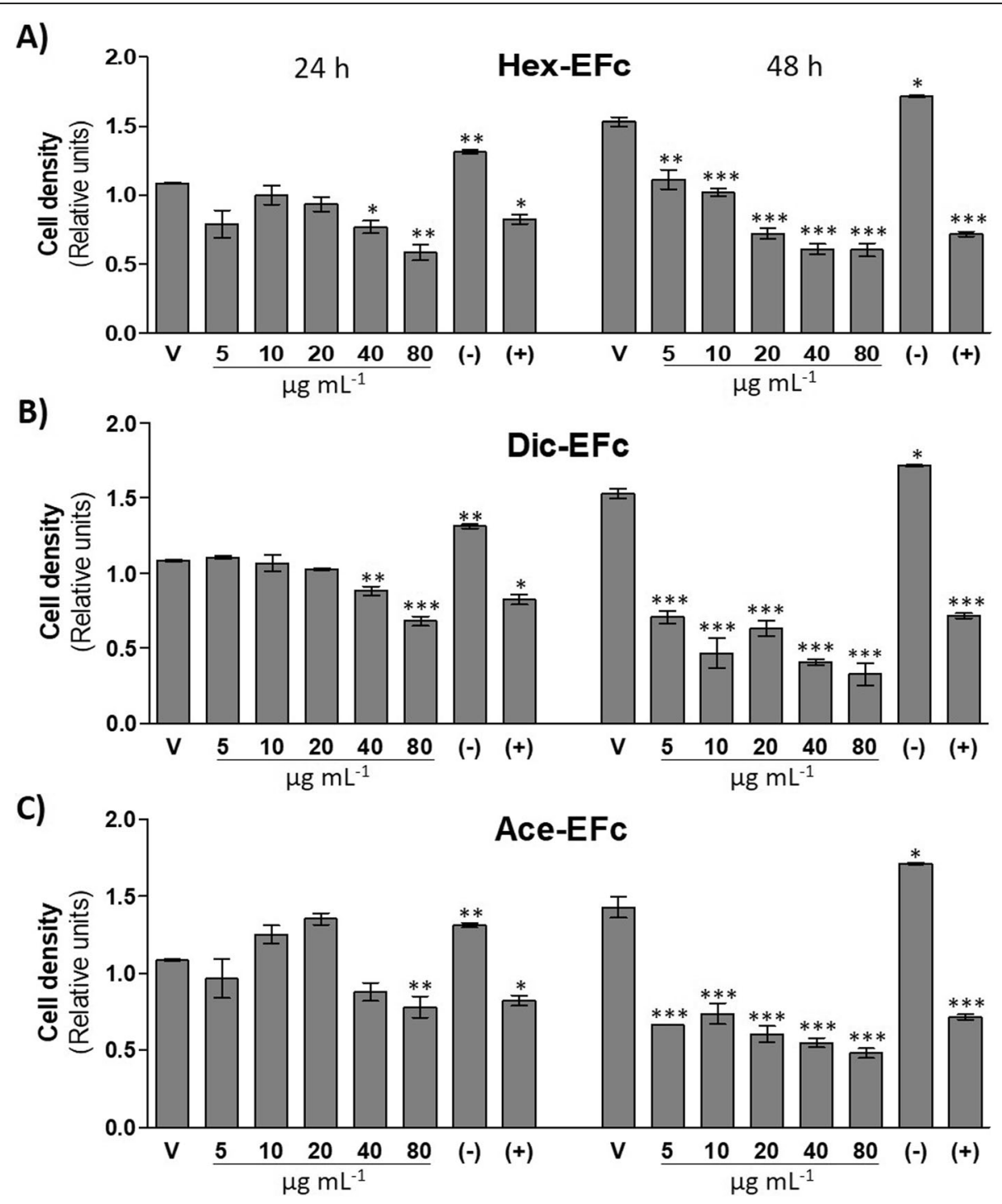

Fig. 1 Effect of extracts of Ficus crocata on the growth in a monolayer of MDA-MB-231 cells. Crystal violet assay; a Hex-EFc: hexane extract of F. crocata. b Dic-EFc: dichloromethane extract of F. crocata. c Ace-EFc: acetone extract of $F$. crocata. V: vehicle, DMSO. (-): negative control, 5\% FBS. (+): positive control, $100 \mu \mathrm{M}$ Ara-C (cytarabine); One-way ANOVA, Dunnett's test: ${ }^{*} p<0.05,{ }^{* *} p<0.01$ and ${ }^{* * *} p<0.001$ versus V

(4.3 and $15 \%$ in early and late apoptosis, respectively). Interestingly, the fractionation of Dic-EFc components enhanced the ability of the extract to induce apoptosis in MDA-MB-231 cells. It was observed that A9-Dic-EFc, A12-Dic-EFc, and A13-Dic-EFc at $80 \mu \mathrm{g} \mathrm{mL}^{-1}$ all induced apoptosis. The A9-Dic-EFc fraction showed the highest percentage of apoptotic cells with 53\% (30.7\% in early apoptosis and $22.3 \%$ in late apoptosis), followed by the A12-Dic-EFc and A13-Dic-EFc fractions, with 51.9 and $48.8 \%$, respectively (Fig. 5). Moreover, a decrease was observed in the cell population in the $\mathrm{S}$ and G2/M phases of the cell cycle, and an increase during the sub-G0 phase was noted after treatment with Dic-EFc and its fractions A9, A12, and A13. A highlighted effect was observed with fraction A9, with more than $50 \%$ of the cell population occurring during the sub-G0 phase (Fig. 6). This high percentage in the sub-G0 phase was consistent with the apoptosis results observed with the Annexin/PI assay.

Exposure to A12-Dic-EFc and A13-Dic-EFc fractions caused an accumulation of G1 phase cells of 62 and $53 \%$, respectively, suggesting that metabolites in these fractions induce a G1-phase cell cycle arrest.

The dichloromethane extract of $F$. crocata increased the p53, procaspase- 8 and procaspase- 3 expression

MDA-MB-231 cells were treated with $0-80 \mu \mathrm{g} \mathrm{mL}^{-1}$ of Dic-EFc and $80 \mu \mathrm{g} \mathrm{mL}^{-1}$ of the A9-Dic-EFc fraction to determine changes in expression of proteins such as p53, procaspase-8, and procaspases-3, which are associated with apoptosis and the cell cycle (Fig. 7). It was 


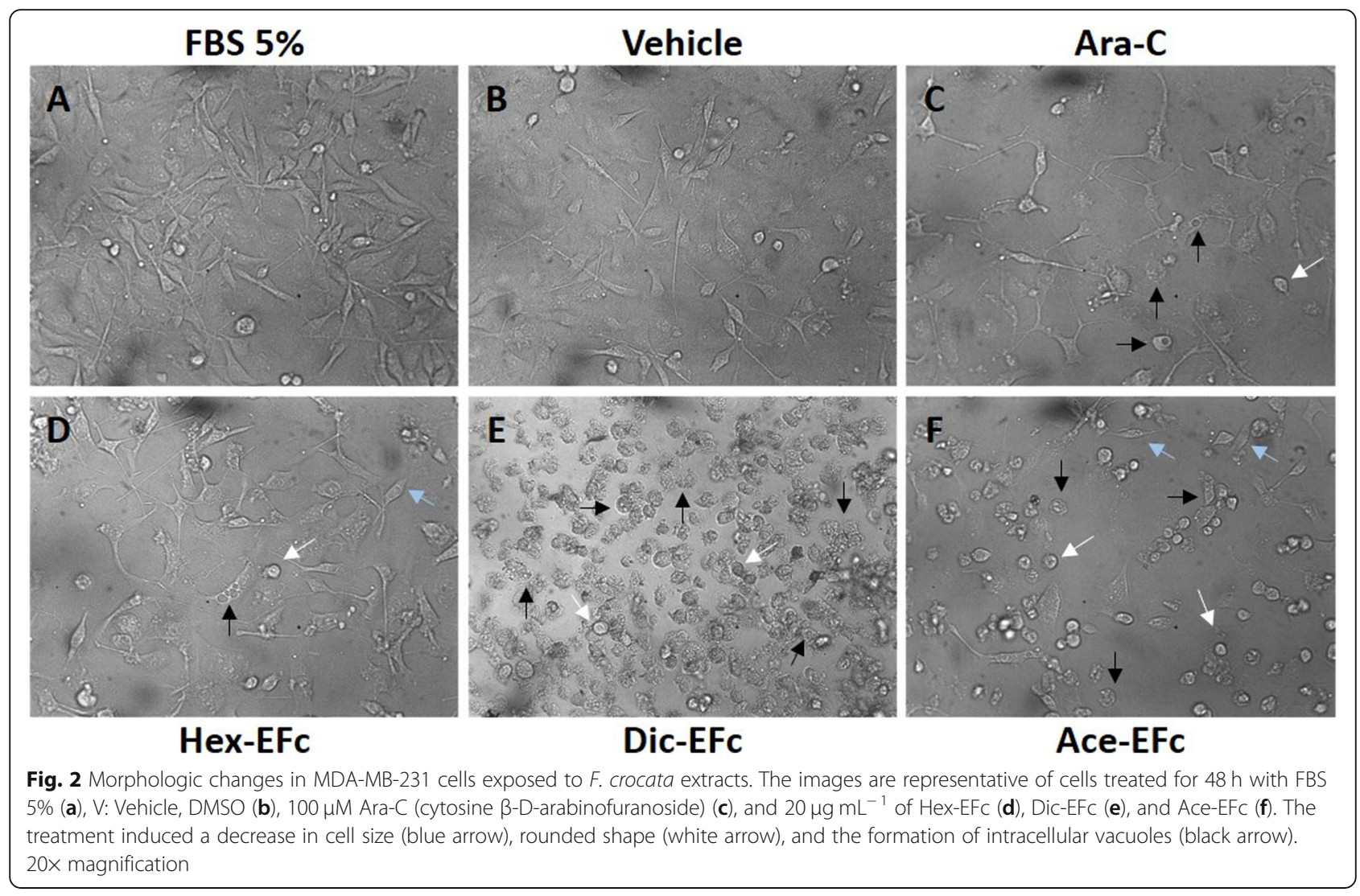

observed that the Dic-EFc and A9 fraction increased p53 expression at $24 \mathrm{~h}$ of treatment (Fig. $7 \mathrm{~b}$ ), although it markedly decreased p53 expression at $48 \mathrm{~h}$ (Fig. 7f). The increase in p53 expression could be associated with the diminution of cell number in the G1 and S phases of the cell cycle. With respect to caspase expression, in Western blot assays, we observed bands around $32 \mathrm{kDa}$ and $55 \mathrm{kDa}$, which correspond to procaspase-3 and procaspase-8, respectively (Fig. 7a and e). Dic-EFc increased procaspase- 8 expression at $48 \mathrm{~h}$ of treatment only at the $80 \mu \mathrm{g} \mathrm{mL}^{-1}$ concentration (Fig. $7 \mathrm{~g}$ ). Minor concentrations $\left(20-40 \mu \mathrm{g} \mathrm{mL}^{-1}\right)$ of Dic-EFc increased procaspase-3 expression at $24 \mathrm{~h}$ and $48 \mathrm{~h}$ of treatment (Fig. $7 \mathrm{~d}$ and h). On the other hand, the A9-Dic-EFc fraction increased procaspase- 8 expression at $24 \mathrm{~h}$ and $48 \mathrm{~h}$ of treatment (Fig. 7c and g), and procaspase- 3 expression at $48 \mathrm{~h} \mathrm{(Fig.} \mathrm{7h).} \mathrm{It} \mathrm{is} \mathrm{possible} \mathrm{that} \mathrm{accumulated}$ procaspase- 3 and procaspase- 8 are being processed into active forms-i.e., caspase 8 and caspase 3 , respectivelywhich contribute to the progression of apoptosis induced mainly by treatment with the A9-Dic-EFc fraction in MDA-MB-231 cells.

\section{Discussion}

TNBC represents $15-20 \%$ of breast cancer cases and is related to poor prognosis, metastasis, and death. This type of breast tumor does not respond to conventional chemotherapy because the cells do not express ER and PR and lack overexpression of the HER2 protein, thus representing the sub-type with worst prognosis among breast cancer cases [66]. Current research is focused on the chemical compounds of plants and their effect on cellular models of cancer [14]. It has been observed that natural products obtained from plants exhibit antiproliferative, antimigratory, and anti-invasive have effects on cancer cells and could be used as adjuvant therapies in cancer [12-15]. Studies conducted in species of the Ficus genus have revealed the greatest antiproliferative potential in cervical, hepatic, leukemia, lung, and coloncancer cell lines $[43,45,47,50]$. It has been described that this activity is due to the presence of compounds such as alkaloids, flavonoids, coumarins, phenols, steroids, terpenoids, and triterpenoids [16, $18,21,23-26,39,40,51,52,54,56,58,59]$. In Mexico, Ficus species are distributed throughout the country $[60,61,67]$, yet there have been no studies, to our knowledge, on the chemical composition or biological properties of the Ficus species distributed in Mexico. In this study, we analyzed the phytochemical profile of leaf extracts of $F$. crocata and their effect on the cell proliferation of TNBC MDA-MB-231 cells. 


\section{Hex-EFc}
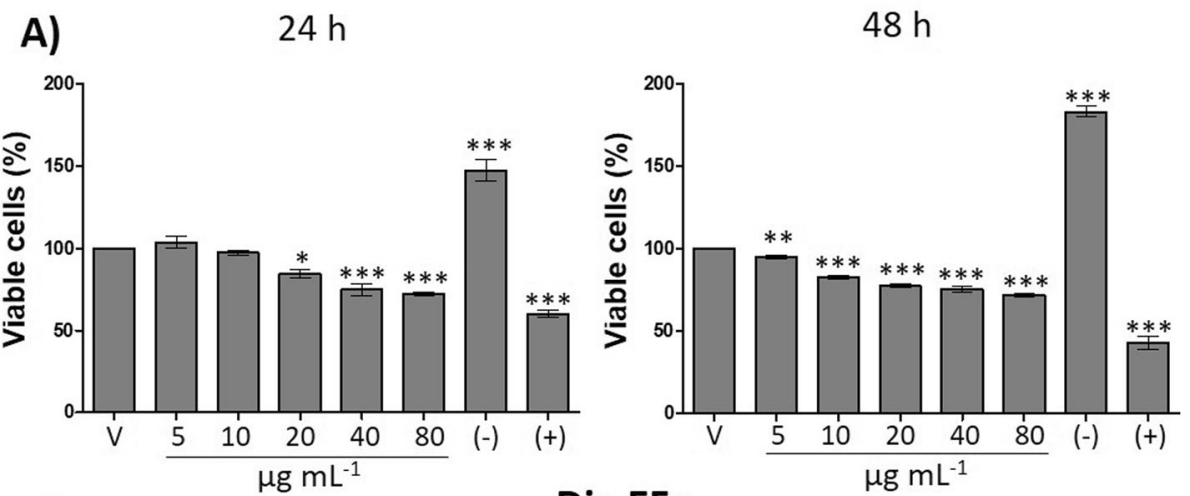

B)

Dic-EFc
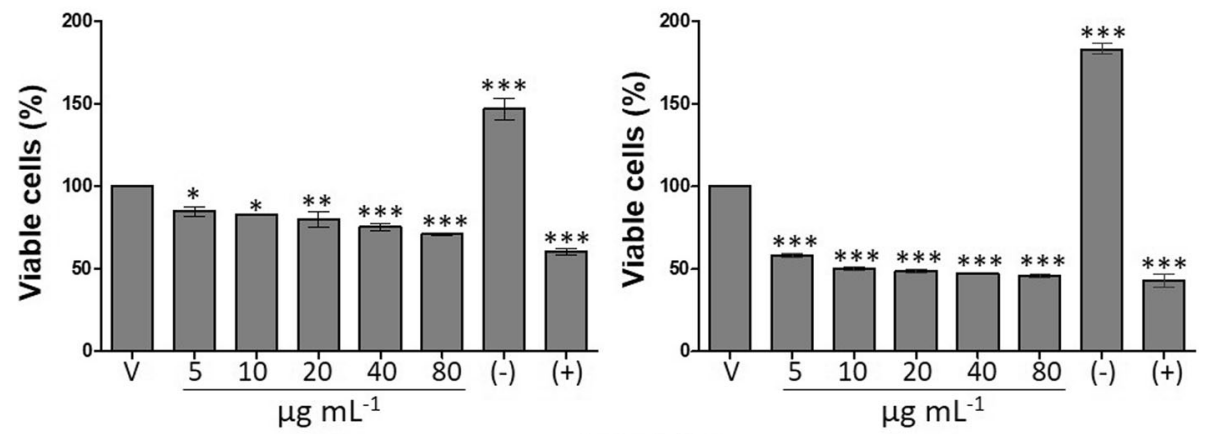

C)

Ace-EFc
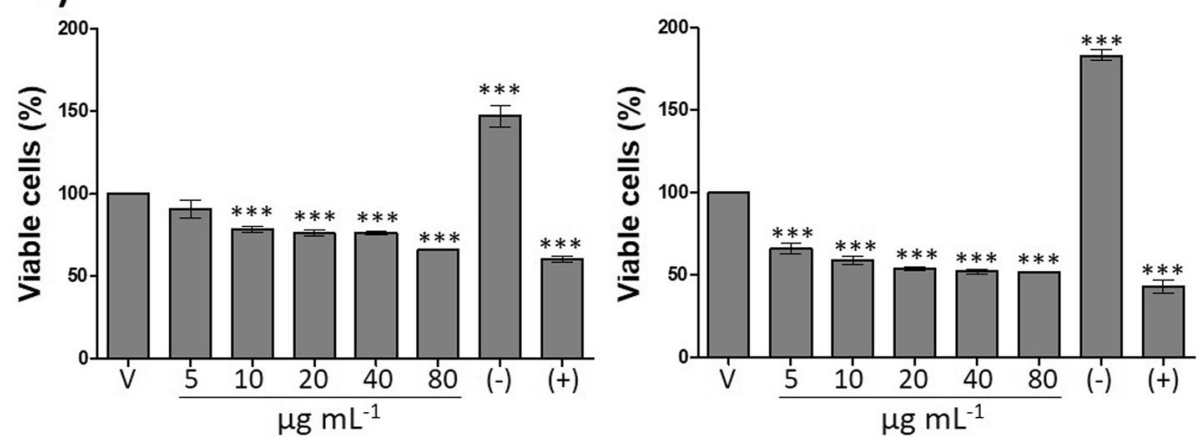

Fig. 3 Effect of leaf extracts of F. crocata on MDA-MB-231 cell viability. MTT assay; V: vehicle, DMSO. (-): negative control, 5\% FBS. (+): positive control, $100 \mu \mathrm{M}$ Ara-C (cytarabine); a Hex-EFc: hexane extract of F. crocata. b Dic-EFc: dichloromethane extract of F. crocata. c Ace-EFc: acetone extract of F. crocata. One-way ANOVA, Dunnett's test: ${ }^{* *} p<0.05,{ }^{* *} p<0.01$ and ${ }^{* * *} p<0.001$ versus $V$

This is the first study, to our knowledge, to evaluate the cytotoxic activity of leaf extracts of F. crocata. We observed that Hex-EFc, Dic-EFc, and Ace-EFc decreased the proliferation of MDA-MB-231 cells, with Ace-EFc and mainly Dic-EFc being the most active. An interesting observation in this study was that Dic-EFc did not show a cytotoxic effect on MCF-10A non-tumor cells at the same concentrations that affected the viability of MDA-MB-231 cells (5-80 $\left.\mu \mathrm{g} \mathrm{mL}^{-1}\right)$, which supports the possible use of extracts of $F$. crocata as an alternative therapy against breast tumors. However, this observation must be analyzed further. These observations are in agreement with other studies, which reported a decrease of cell viability in the breast cancer cell lines T47D and MDA-MB-231 exposed to the leaf extracts of Ficus septica Burm. and Ficus carica [56, 68].

To separate compounds into groups based on their polarity, Dic-EFc was fractionated and we observed that the A9-Dic-EFc, A12-Dic-EFc, and A13-Dic-EFc fractions exerted a greater effect in terms of decreasing the viability of MDA-MB-231 cells. A9-Dic-EFc was the most effective of the fractions, as compared to Dic-EFc. This effect suggests that isolation of compounds increased their biological activity. The phytochemical 


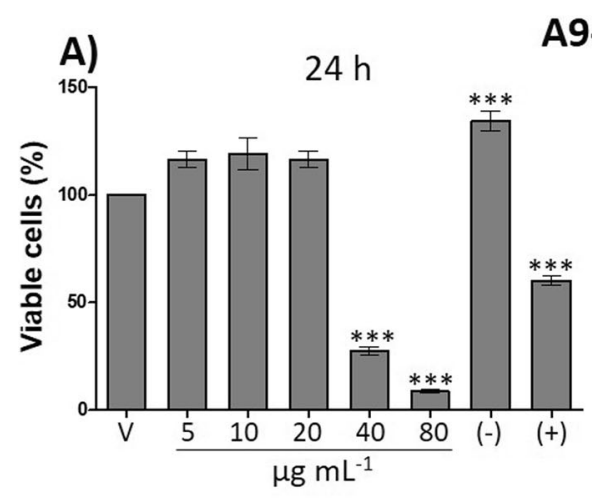

A9-Dic-EFc

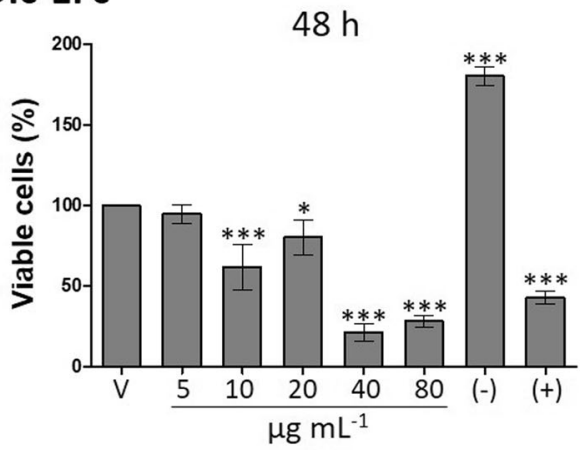

A12-Dic-EFc
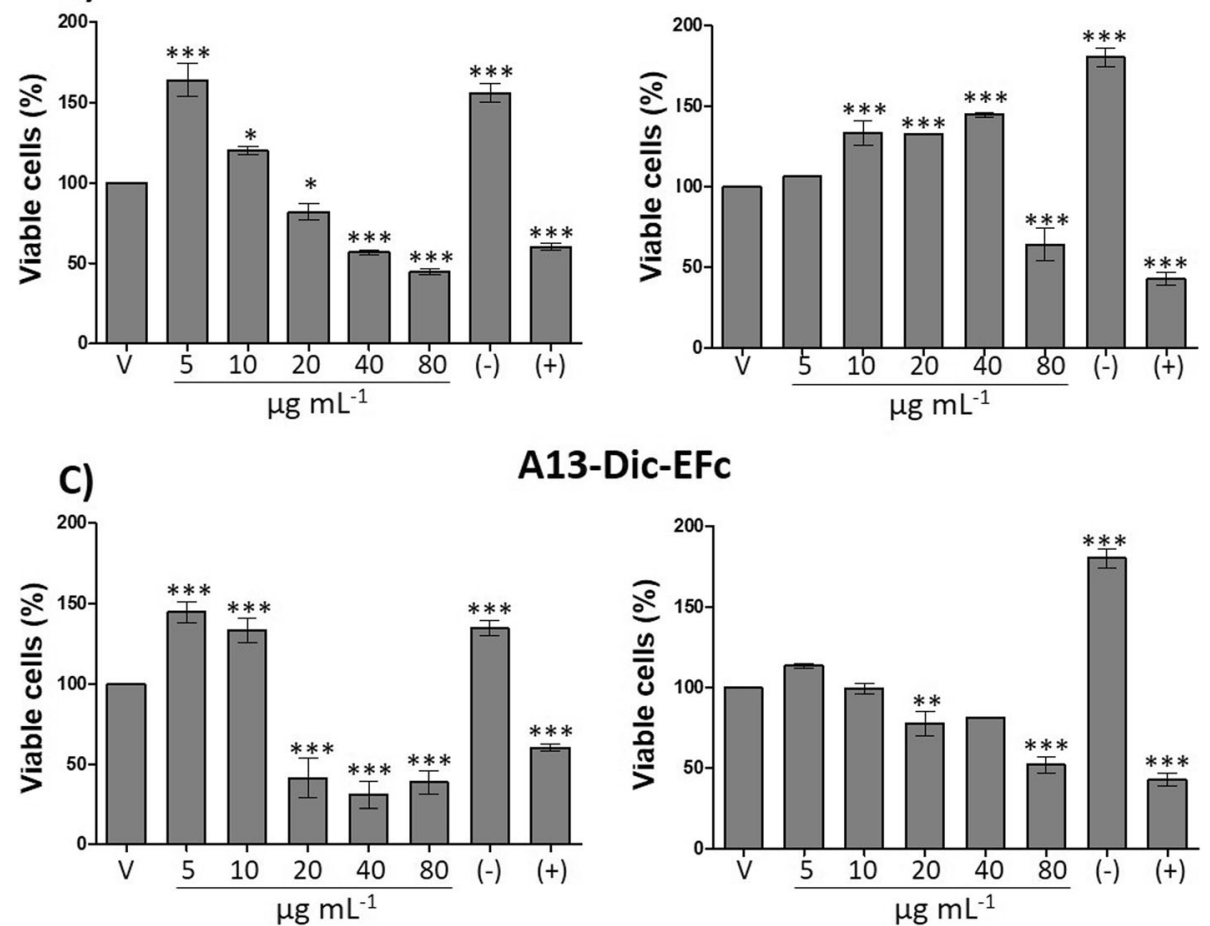

Fig. 4 Effect of A9-, A12-, and A13-Dic-EFc fractions on MDA-MB-231 cells viability. MTT assay. a A9-Dic-EFc fraction, (b) A12-Dic-EFc fraction, (c) A13-Dic-EFc fraction. V: vehicle, DMSO. V: vehicle, DMSO. (-): negative control, 5\% FBS. (+): positive control, $100 \mu \mathrm{M}$ Ara-C (cytarabine); One-way ANOVA, Dunnett's test: ${ }^{*} p<0.05,{ }^{* *} p<0.01$ and ${ }^{* *} p<0.001$ versus $V$

composition of Dic-EFc and the A9-Dic-EFc, A12-DicEFc, and A13-Dic-EFc fractions revealed the presence of alkaloids, coumarins, lignans, anthraquinones, phenols, terpenoids, and triterpenoids. The presence of these compounds has already been reported for the Ficus genus, and it has been demonstrated that these compounds possess biological activity $[16,46,56,59]$.

We observed that the exposure of MDA-MB-231 cells to $F$. crocata extracts induced morphological changes such as a decrease in cell size, a rounded shape, and the formation of intracellular vacuoles. In a concentrationdependent manner, Dic-EFc and A9-Dic-EFc decreased the cell population in the $\mathrm{S}$ and $\mathrm{G} 2 / \mathrm{M}$ phases of the cell cycle and increased the cell population in the sub-G0, which was consistent with the increase of apoptotic cells that could explain the morphologic changes in the cells and the decrease in cell viability. The apoptotic effect of Dic-EFc was potentiated with the A9-Dic-EFc, A12-Dic$E F c$, and A13-Dic-EFc fractions, inducing apoptosis in around $50 \%$ of the cell population. In this regard, we observed that Dic-EFc and the A9-Dic-EFc fraction increased p53 expression at $24 \mathrm{~h}$ of treatment, which could be associated with apoptosis and cell cycle arrest, but curiously, p53 expression markedly decreased after of $48 \mathrm{~h}$ with $80 \mu \mathrm{g} \mathrm{mL}^{-1}$ of Dic-EFc and A9-Dic-EFc. This increase and a subsequent decrease in the expression of 


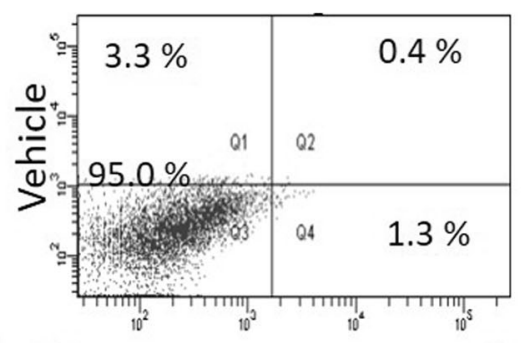

Dic-EFc
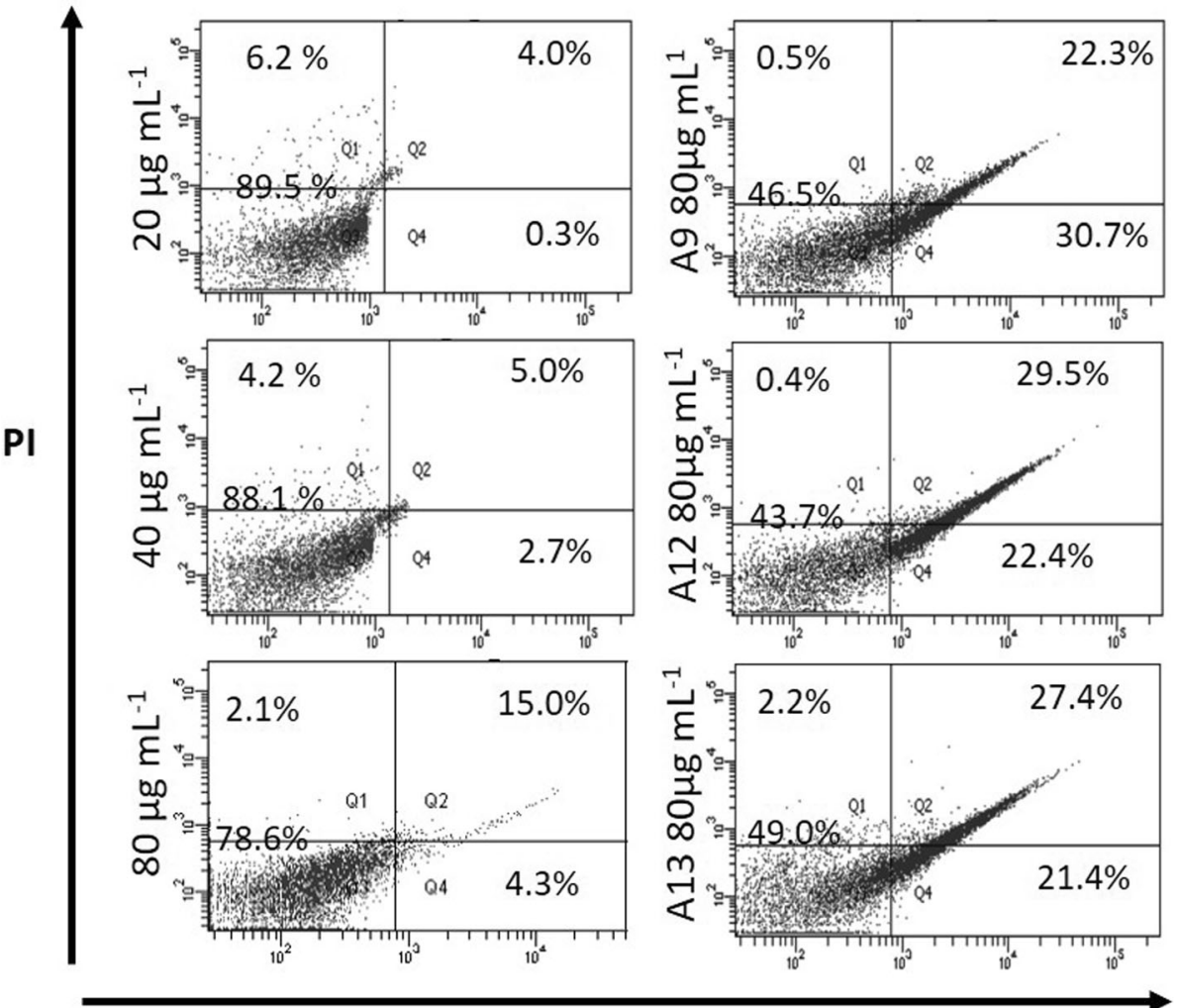

\section{Annexin V}

Fig. 5 Dic-EFc and the A9-, A12-, and A13-Dic-EFc fractions induced apoptosis in MDA-MB-231 cells. Representative pictograms of cells treated as indicated for 48 h. Q3: viable cells. Q4: Annexin V-positive (early-apoptotic cells). Q2: Annexin V/PI double-positive (late-apoptotic cells). Q1: dead cells (no apoptosis). Vehicle: cells treated with 1\% DMSO

p53 has also been observed in another study with HCT116 cells treated with betulinic acid (BA), in which the treatment also induced apoptosis, suggesting that other proteins could be involved in BA-induced apoptosis in addition to p53 [69]. Moreover, in breast cancer cell lines MCF-7 and MDA-MB-231, it was observed that Vernonia amygdalina (VA) extracts induced apoptosis and cell cycle arrest in a p53-independent manner. Interestingly, these authors observed that VA increased p53 expression in a time-dependent manner in MCF-7 cells, whereas in MDA-MB-231, p53 expression decreased after $48 \mathrm{~h}$ [70]. We observed a similar event in our study. On the other hand, the A9-Dic-EFc fraction increased the expression of procaspase-8 and procaspase-3, which are initiator and executioner caspases, respectively, involved in the extrinsic apoptosis pathway [71]. These proteins could be processed in their active form and induce apoptosis, which would explain the increase in the apoptotic cell population induced mainly by the A9-Dic-EFc fraction in MDA-MB-231 cells. Dic-EFc also increased procaspase- 8 expression at $48 \mathrm{~h}$ of treatment at an $80 \mu \mathrm{g} \mathrm{mL}^{-1}$ concentration, while $20-40 \mu \mathrm{g} \mathrm{mL}^{-1}$ concentrations increased procaspase-3 expression, which could be associated with the slight increase in the apoptotic cell population under these treatment conditions. It is probable that the apoptosis induced by the extracts of $F$. crocata and its fractions in MDA-MB-231 cells is through an p53-independent 


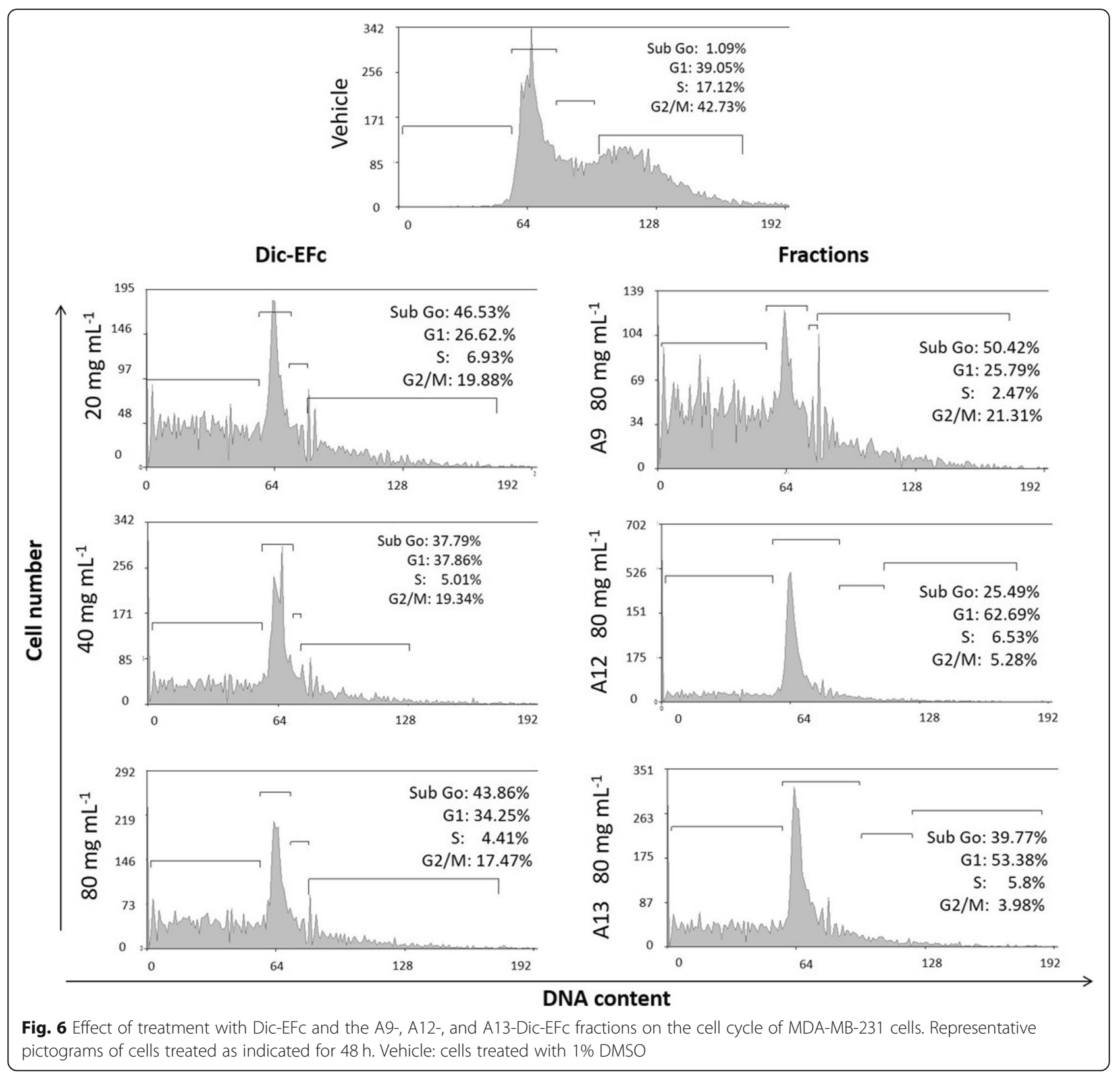

pathway, such as PUMA protein for example, which is known to be a powerful apoptosis inducer associated or not with p53 [72]. However, this hypothesis should still be tested.

Our observations are consistent with those of other studies. Zhang et al. (2018) reported that F. carica extracts induce apoptosis and cell cycle arrest at the $\mathrm{S}$ phase in MDA-MB-231 cells, increasing the expression of genes that promote apoptosis and the regulation of the cell cycle, such as BAX, TP53, and TP21 [68]. Similarly, in a study by Choudhari et al., the authors reported that the aqueous extract of Ficus religiosa induces cell cycle arrest in the G1 phase in SiHa cells, accompanied by an increase in the expression of p53, p21, and pRb proteins. Moreover, in HeLa cells, the extract induces apoptosis through an increase in intracellular $\mathrm{Ca}^{2+}$, leading to the loss of mitochondrial membrane potential, the release of cytochrome- $\mathrm{C}$, and an increase in caspase- 3 expression [47]. It has also been reported that the flavonoid quercetin induces apoptosis in HeLa cells, promoting the accumulation of reactive oxygen species (ROS), upregulating proapoptotic proteins such as cytochrome C, Apaf-1, and caspases, and downregulating the antiapoptotic proteins Bcl-2 and survivin [73, 74].

The primary compound in Dic-EFc was lupeol, a triterpene also present in Ace-EFc and Hex-EFc, although in smaller proportions (Table 1). Triterpenes were only present in the A9-Dic-EFc fraction, which suggests that 


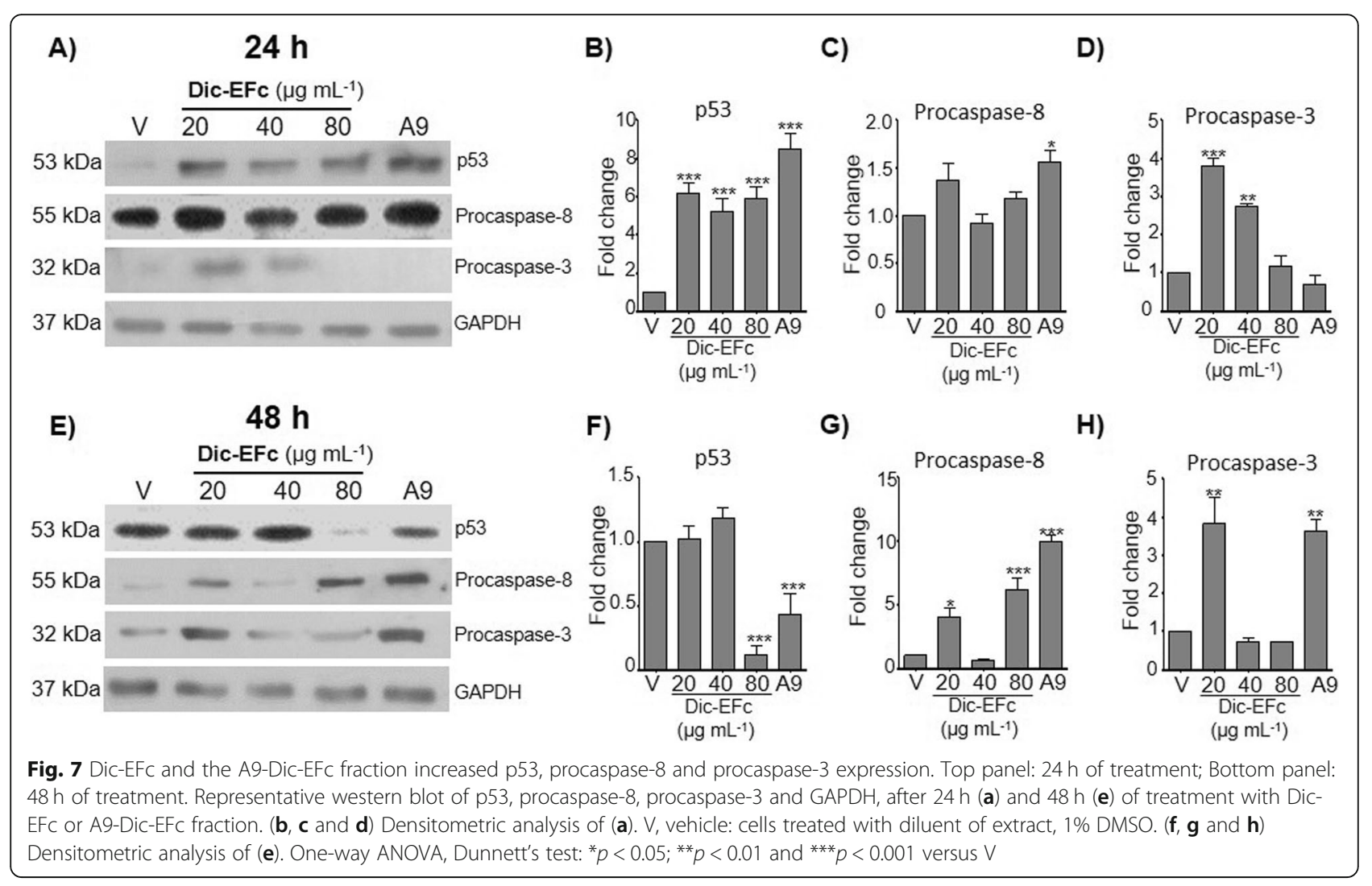

lupeol was only present in A9-Dic-EFc and not in the A12- and A13-Dic-EFc fractions. It has been reported that lupeol induces apoptosis and cell cycle arrest in several cancer cell lines. For example, in pancreatic cancer cells, lupeol induces apoptosis by decreasing the levels of p-AKT and p-ERK, as well as cell cycle arrest in the G0/G1 phase, by upregulating P21 and P27 and downregulating cyclin D1 proteins [75]. A similar effect was observed in osteosarcoma cells MNNG/HOS and MG-63 [76]. In gallbladder carcinoma GBC-SD cells, lupeol was shown to induce apoptosis and inhibit invasion by downregulating the activity of p-EGFR and MMP-9 [77]. In non-small cell lung cancer cells, it was observed that lupeol inhibits the phosphorylation of EGFR by binding to its tyrosine kinase domain and reducing STAT3 phosphorylation, which contributes to the induction of apoptosis [78]. In the hepatocarcinoma cell lines SMMC7721 and HepG2 as well as lung carcinoma A427 cells, lupeol was shown to induce low expression of the antiapoptotic protein $\mathrm{Bcl}-2$ and upregulate the proapoptotic protein BAX $[79,80]$. Considering the previously noted observations, it is possible that the metabolites present in $F$. crocata extracts, such as lupeol, probably in synergy with other metabolites, induce cell cycle arrest and apoptosis in MDA-MB-231 cells, altering the expression of cell cycle regulatory proteins such as p53, p21, p27, and cyclins, as well as the expression of anti- and proapoptotic proteins, such as caspases, PUMA, Bax, and Bak. However, this hypothesis still needs to be further analyzed.

One limitation of this study is that the assays were executed in only one breast cancer cell line. It would be important to evaluate the effect of $F$. crocata extracts on a larger number of tumor and non-tumor cell lines. Furthermore, the effect of pure metabolites isolated from F. crocata extracts, such as lupeol, Stigmastan, and others, has not, to our knowledge, been tested. This effect will be evaluated in a subsequent study. Our observations comprise, to our knowledge, a first approach to investigating the possible use of extracts of $F$. crocata as alternative or complementary therapy against cancer. Nonetheless, their cytotoxicity and molecular mechanisms must be analyzed in more study models.

\section{Conclusions}

The leaf extract of $F$. crocata decreases the proliferation capacity of MDA-MB-231 triple-negative breast cancer cells, decreasing the $\mathrm{S}$ and $\mathrm{G} 2 / \mathrm{M}$ cell cycle phases, and inducing apoptosis possibly through an p53-independent pathway. By fractionating the extract, the antiproliferative activity against MDA-MB-231 cells can be further potentiated. These findings provide information on the 
biological activity of $F$. crocata extracts and suggest their potential use as an alternative or complementary therapy against triple-negative breast cancer. Nevertheless, more studies are required to determine the components responsible for this biological activity, as well as the molecular and cellular mechanisms involved.

\section{Supplementary information}

Supplementary information accompanies this paper at https://doi.org/10. 1186/s12906-020-02993-6.

Additional file 1: Fig. S1. Structures of the molecules identified by GC/ MS from the Hex-EFc. The numbers correspond to name of compounds shown in Table 1.

Additional file 2: Fig. S2. Structures of the molecules identified by GC/ MS from the Dic-EFc. The numbers correspond to name of compounds shown in Table 1.

Additional file 3: Fig. S3. Structures of the molecules identified by GC/ MS from the Ace-EFc. The numbers correspond to name of compounds shown in Table 1.

Additional file 4: Fig. S4. Half-maximal inhibitory concentration $\left(\mathrm{IC}_{50}\right)$ of leaf $F$. crocata extracts and fractions on cell proliferation (MTT assay).

Additional file 5: Fig. S5. Effect of Dic-EFC on MCF-10A cell viability after $48 \mathrm{~h}$ of treatment. MTT assay; V: vehicle, DMSO. (-): negative control, 5\% FBS. (+): positive control, $100 \mu \mathrm{M}$ Ara-C (cytarabine); Dic-EFc: dichloromethane extract of $F$. crocata. One-way ANOVA, Dunnett's test: ${ }^{* *} p<0.05$, ${ }^{* *} p<0.01$ and ${ }^{* *} p<0.001$ versus $V$.

Additional file 6: Table S1. Phytochemical profile of the dichloromethane extract fractions of $F$. crocata leaves.

Additional file 7: Fig. S6. Full Images of the blots shown in Fig. 7. V: Vehicle (DMSO), B: Basal, cells without treatment. Arrow: row of bands corresponding to p53, procaspase-8, procaspase 3 and GAPDH shown in Fig. 7. Red box: data not shown in Fig. 7; The Basal condition was omitted.

\section{Abbreviations}

Hex-EFc: Hexane extract of F. crocata; Dic-EFc: Dichloromethane extract of $F$. crocata; Ace-EFc: Acetone extract of F. crocata; GC-MS: Gas chromatography coupled with mass analysis; TNBC: Triple-negative breast cancer; ER: Estrogen receptors; PR: Progesterone receptors; OCC: Open glass Column Chromatography; DMEM: Dulbecco's Modified Eagle Medium; FBS: Fetal bovine serum; DMSO: Dimethyl Sulfoxide; Ara-C: Cytarabine, cytosine $\beta$-Darabinofuranoside; PBS: Phosphate-Buffered Saline;

RIPA: Radioimmunoprecipitation assay buffer; HEPES: 4-(2-hydroxyethyl)-1piperazineethanesulfonic acid; EDTA: Ethylene-diamine-tetraacetic acid; EGTA: Ethylene glycol tetraacetic acid; OD: Optical density; $\boldsymbol{I}_{50}$ : Half-maximal inhibitory concentration; PI: Propidium iodide; RT: Room temperature; SD: Standard deviation; ANOVA: One-way analysis of variance

\section{Acknowledgements}

The authors wish to thank QBP Natividad Sales, QBP Karina Melquiades, and QBP Gabriela García for their technical assistance in the project, and the INHA Botanical Garden at Cuernavaca, Morelos, particularly Biol. Margarita Avilés, B.Sc. Biology, and Macrina Fuentes, B.Sc. Biology.

\section{Authors' contributions}

CASV and PAF contributed equally in the work, performed the experimental procedures, and analyzed the data. JUCR participated in the collection of $F$. crocata leaves, extraction, and the phytochemical profile of compounds. LCS and MAQ participated in Analysis GC-MS. AEZG and NNT participated in cell culture and analyzed the data of cell proliferation and viability. COP, YCC, MALV and JOO participated in data analysis of cell cycle and apoptosis assays by flow cytometry. MOF and COP performed the western blot analysis. MAMC and PAF conceived the project, designed experiments, data analysis, and wrote the manuscript. All authors read and approved the final version of the manuscript.

\section{Funding}

The materials and reagents necessary for this research were acquired with the support of Universidad Autónoma de Guerrero through SEMILLA 2018 grant. C.A.S.-V. received a postgraduate Master fellowship from the National Council of Science and Technology (CONACYT).

\section{Availability of data and materials}

All data generated or analyzed during this study are included in this published article and its supplementary information files.

Ethics approval and consent to participate

Not applicable.

\section{Consent for publication}

Not applicable.

\section{Competing interests}

The authors declare that they have no competing interests.

\section{Author details}

${ }^{1}$ Facultad de Ciencias Químico Biológicas, Universidad Autónoma de Guerrero, Av. Lázaro Cárdenas, Ciudad Universitaria, 39090 Chilpancingo, Guerrero, Mexico. ${ }^{2}$ CONACYT-Universidad Autónoma de Guerrero, Chilpancingo, Guerrero, Mexico. ${ }^{3}$ Tecnológico Nacional de México, Instituto Tecnológico de Zacatepec, Calzada Tecnológico 27, Centro, 62780 Zacatepec, Morelos, Mexico.

Received: 18 February 2020 Accepted: 16 June 2020

Published online: 22 June 2020

\section{References}

1. Ferlay J, Soerjomataram I, Dikshit R, Eser S, Mathers C, Rebelo M, Parkin DM, Forman D, Bray F. Cancer incidence and mortality worldwide: sources, methods and major patterns in GLOBOCAN 2012. Int J Cancer. 2015;136: E359-86. https://doi.org/10.1002/ijc.29210.

2. Badve S, Dabbs DJ, Schnitt SJ, Baehner FL, Decker T, Eusebi V, Fox SB, Ichihara S, Jacquemier J, Lakhani SR, Palacios J, Rakha EA, Richardson AL, Schmitt FC, Tan PH, Tse GM, Weigelt B, Ellis IO, Reis-Filho JS. Basal-like and triple-negative breast cancers: a critical review with an emphasis on the implications for pathologists and oncologists. Mod Pathol. 2011;24:157-67. https://doi.org/10.1038/modpathol.2010.200.

3. Dai X, Li T, Bai Z, Yang Y, Liu X, Zhan J, Shi B. Breast cancer intrinsic subtype classification, clinical use and future trends. Am J Cancer Res. 2015;5:2929-43.

4. Kalimutho M, Parsons K, Mittal D, Lopez JA, Srihari S, Khanna KK. Targeted therapies for triple-negative breast Cancer: combating a stubborn disease. Trends Pharmacol Sci. 2015;36:822-46. https://doi.org/ 10.1016/j.tips.2015.08.009.

5. Ramos AYD, Marmón TER, Crespo GC, Junco SB, Valiente MW. Breast cancer, its epidemiological characterization. Rev. Ciencias Médicas. 2015;19:619-29.

6. Poschner S, Maier-Salamon A, Thalhammer T, Jäger W. Resveratrol and other dietary polyphenols are inhibitors of estrogen metabolism in human breast cancer cells. J Steroid Biochem Mol Biol. 2019;190:11-8. https://doi.org/10. 1016/j.jsbmb.2019.03.001.

7. Shay J, Elbaz HA, Lee I, Zielske SP, Malek MH, Hüttemann M. Molecular mechanisms and therapeutic effects of (-)-epicatechin and other polyphenols in cancer, inflammation, diabetes, and neurodegeneration. Oxidative Med Cell Longev. 2015:181260-13. https://doi.org/10.1155/2015/ 181260.

8. Losada-Echeberría M, Herranz-López M, Micol V, Barrajón-Catalán E. Polyphenols as promising drugs against main breast cancer signatures. Antioxidants. 2017;6(4):88. https://doi.org/10.3390/antiox6040088.

9. Srivastava S, Somasagara RR, Hegde M, Nishana M, Tadi SK, Srivastava M, Raghavan SC. Quercetin, a natural flavonoid interacts with DNA, arrests cell cycle and causes tumor regression by activating mitochondrial pathway of apoptosis. Sci Rep. 2016;6(1):24049. https://doi.org/10.1038/srep24049.

10. Jiang K, Wang W, Jin X, Wang Z, Ji Z, Meng G. Silibinin, a natural flavonoid, induces autophagy via ROS-dependent mitochondrial dysfunction and loss of ATP involving BNIP3 in human MCF7 breast cancer cells. Oncol Rep. 2015;33(6):2711-8. https://doi.org/10.3892/or.2015.3915. 
11. Martínez-Pérez C, Ward C, Turnbull AK, Mullen P, Cook G, Meehan J, Langdon SP. Antitumour activity of the novel flavonoid oncamex in preclinical breast cancer models. Br J Cancer. 2016;114(8):905-16. https://doi. org/10.1038/bjc.2016.6

12. Amin A, Gali-Muhtasib H, Ocker M, Schneider-Stock R. Overview of major classes of plant-derived anticancer drugs. Int J Biomed Sci. 2009:5:1-11.

13. Greenwell M, Rahman PK. Medicinal Plants: Their Use in Anticancer Treatment. Int J Pharm Sci Res. 2015;6:4103-12. https://doi.org/10.13040/ IJPSR.0975-8232.6 (10).4103-12.

14. Seca AML, Pinto D. Plant secondary metabolites as anticancer agents: successes in clinical trials and therapeutic application. Int J Mol Sci. 2018; 19(1):E263. https://doi.org/10.3390/ijms19010263.

15. Weaver BA. How Taxol/paclitaxel kills cancer cells. Mol Biol Cell. 2014;25: 2677-81. https://doi.org/10.1091/mbc E14-04-0916.

16. Mawa S, Husain K, Jantan I. Ficus carica L. (Moraceae): Phytochemistry, traditional uses and biological activities. Evid Based Complement Alternat Med. 2013;2013:974256. https://doi.org/10.1155/2013/974256.

17. Bouasla A, Bouasla I. Ethnobotanical survey of medicinal plants in northeastern of Algeria. Phytomedicine. 2017;36:68-81. https://doi.org/10. 1016/j.phymed.2017.09.007

18. Chee-Yan C, Sulong SY. A review on the phytochemicals, ethnomedicine uses and pharmacology of Ficus species. Curr Traditl Med. 2016;2(1):3-17. https://doi.org/10.2174/2215083802999160722152307.

19. Neamsuvan O, Komonhiran P, Boonming K. Medicinal plants used for hypertension treatment by folk healers in Songkhla province, Thailand. J Ethnopharmacol. 2018;214:58-70. https://doi.org/10.1016/j.jep.2017.11.032.

20. Ahmed AF, Mueen AK, Abedin M, Karim A. Traditional uses and pharmacological potential of Ficus exasperata Vahl. Sys Rev Pharm. 2012;3(1): 15-23.

21. Shiksharthi AR, Mittal S. Ficus racemosa: Phytochemistry, traditional uses and pharmacological properties: a review. Int J Adv Pharm Res. 2011;4:6-15.

22. Abusufyan S, Ibrahim M, Mohib K. Comparative in vitro antidiabetic and antioxidant activity of various extracts of Ficus species. Pharm J. 2018;10(2): 349-54. https://doi.org/10.5530/pj.2018.2.59.

23. Devanesan AA, Zipora TG, Smilin BA, Deviram G, Thilagar S. Phytochemical and pharmacological status of indigenous medicinal plant Pedalium murex L.-a review. Biomed Pharmacother. 2018;103:1456-63. https://doi.org/10. 1016/j.biopha.2018.04.177.

24. Sirisha N, Sreenivasulu M, Sangeeta K, Chetty CM. Antioxidant properties of Ficus species - a review. IntJ PharmTech Res. 2010;2(4):2174-82.

25. Taviano MF, Rashed K, Filocamo A, Cacciola F, Dugo P, Mondello L, Bisignano C, Acquaviva R, D'Arrigo M and Miceli N. Phenolic profile and biological properties of the leaves of Ficus vasta Forssk. (Moraceae) growing in Egypt. BMC Complement Altern Med 2018; 18: 161. DOl: https://doi.org/ 10.1186/s12906-018-2210-0

26. Ajaib M, Almas M, Khan KM, Perveen S, Shah S. Phytochemical screening, antimicrobial and antioxidant activities of Ficus natalensis. J Chem Soc Pak. 2016;38(2):345-51.

27. Bhawana R, Kaur J, Pal Vig A, Arora S, Kaur R. Evaluation of antibacterial potential of Ficus species. J Pharm Sci Res. 2018;10(5):1251-5.

28. Yessoufou K, Elansary HO, Mahmoud Eman A, Skalicka-Wòzniak K. Antifungal, antibacterial and anticancer activities of Ficus drupacea L. stem bark extract and biologically active isolated compounds. Ind Crop Prod. 2015;74:752-8. https://doi.org/10.1016/j.indcrop.2015.06.011.

29. Azam S, Ishtiag M, Magbool M, Mushtag W, Mehmood H, Azam A, Shahman M. Antimicrobioal potential of leaves of four ficus species from district Bhimber Azad Kashmir, Pakistan. Pak J Bot. 2017:49:211-20.

30. Cagno V, Civra A, Kumar R, Pradhan S, Donalisio M, Sinha BN, Ghosh M, Lembo D. Ficus religiosa L. bark extracts inhibit human rhinovirus and respiratory syncytial virus infection in vitro. J Ethnopharmacol. 2015;176:2527. https://doi.org/10.1016/j.jep.2015.10.042.

31. Ghosh M, Civra A, Ritta M, Cagno V, Mavuduru SG, Awasthi P, Lembo D, Donalisio M. Ficus religiosa L. bark extracts inhibit infection by herpes simplex virus type 2 in vitro. Arch Virol. 2016;161(2):3509-14. https://doi.org/ 10.1007/s00705-016-3032-3

32. Lazreg Aref H, Gaaliche B, Fekih A, Mars M, Aouni M, Pierre Chaumon J, Said K. In vitro cytotoxic and antiviral activities of Ficus carica latex extracts. Nat Prod Res. 2011;25(3):310-9. https://doi.org/10.1080/14786419.2010.528758.

33. Anasane PD, Chaturvedi A. Evaluation of anti-inflammatory effects if Ficus hispida L. leaves extract against carageenan induced paw edema in rats. J Pharm Sci Res. 2017;9(4):364-7.
34. Ghori SS, Khan M, Tabassum R. Anti-inflammatory activity of Ficus dalhousiae miq roots ethanolic extract in wistar albino rats. Asian J Pharm Clin Res. 2015;8(1):117-9.

35. Panday DR, Rauniar GP. Effect of root-extracts of Ficus benghalensis (banyan) in memory, anxiety, muscle co-ordination and seizure in animal models. BMC Complement Altern Med. 2016;16:429. https://doi.org/10.1186/s12906016-1413-5.

36. Yang Y, Zheng K, Mei W, Wang Y, Yu C, Yu B, Deng S, Hu J. Antiinflammatory and proresolution activities of bergapten isolated from the roots of Ficus hirta in an in vivo zebrafish model. Biochem Biophys Res Commun. 2018:496(2):763-9. https://doi.org/10.1016/j.bbrc.2018.01.071.

37. Desrivot J, Waikedre J, Cabalion P, Herrenknecht C, Bories C, Hocquemiller R, Fournet A. Antiparasitic activity of some new Caledonian medicinal plants. J Ethnopharmacol. 2007;112(1):7-12.

38. Deepa P, Sowndhararajan K, Kim S, Park SJ. A role of Ficus species in the management of diabetes mellitus: a review. J Ethnopharmacol. 2018;215: 210-32. https://doi.org/10.1016/j.jep.2017.12.045.

39. Olaokun OO, McGaw LJ, Janse VI, Eloff JN, Naidoo V. Antidiabetic activity of the ethyl acetate fraction of Ficus lutea (Moraceae) leaf extract: comparison of an in vitro assay with an in vivo obese mouse model. BMC Complement Altern Med. 2016;16:110. https://doi.org/10.1186/s12906-016-1087-z.

40. Solanki ND, Bhavsar SK. Evaluation of phytochemical profile and antidiabetic activity of Ficus racemosa (Linn.) stem bark in rats. Indian Drugs. 2017;54(1): 49-54.

41. Stephen IS, Christudas S, Antony S, Duraipandiyan V, Naif Abdullah AD, Ignacimuthu S. Protective effects of Ficus carica leaves on glucose and lipids levels, carbohydrate metabolism enzymes and beta-cells in type 2 diabetic rats. Pharm Biol. 2017;55(1):1074-81. https://doi.org/10.1080/13880209.2017. 1279671.

42. Yahaya N, Mohd Dom NS, Adam Z and Hamid M. Insulinotropic Activity of Standardized Methanolic Extracts of Ficus deltoidea from Seven Varieties. Evid Based Complement Alternat Med 2018; 2018: 3769874. DOl: https://doi. org/10.1155/2018/3769874

43. Abubakar IB, Lim KH, Loh HS. Alkaloid extracts of Ficus species and palm oilderived tocotrienols synergistically inhibit proliferation of human cancer cells. Nat Prod Res. 2015;29(22):2137-40. https://doi.org/10.1080/14786419. 2014.991927.

44. Raheel R, Saddique Z, Iram M, Afzal S. In vitro antimitotic, antiproliferative and antioxidant activity of stem bark extracts of Ficus benghalensis L. S Afr J Bot. 2017;11:248-57. https://doi.org/10.1016/j.sajb.2017.03.037.

45. Larbie C, Appiah-Opong R, Acheampong F, Tuffour I, Uto T, Yeboah GA, Abboah-Offei O, Tagoe DNK, Inkabi SE. Anti-proliferative effect of Ficus pumila Linn. On human leukemic cell lines. Int J Basic Clin Pharmacol. 2015; 4:257-61.

46. Parveen M, Malla AM, Alam M, Ahmad F, Silva PS, Silva MR. Two new phenolic compounds from Ficus rumphii and their antiproliferative activity. Nat Prod Res. 2014;28:646-52. https://doi.org/10.1080/14786419.2014.891201.

47. Choudhari AS, Suryavanshi SA, Kaul-Ghanekar R. The aqueous extract of Ficus religiosa induces cell cycle arrest in human cervical cancer cell lines SiHa (HPV-16 positive) and apoptosis in HeLa (HPV-18 positive). PLoS One. 2013;8:e70127. https://doi.org/10.1371/journal.pone.0070127.

48. Hanafi MMM, Afzan A, Yaakob H, Aziz R, Sarmidi MR, Wolfender JL and Prieto JM. In Vitro Pro-apoptotic and Anti-migratory Effects of Ficus deltoidea L. Plant Extracts on the Human Prostate Cancer Cell Lines PC3. Front Pharmacol 2017; 8: 895. DOl: https://doi.org/10.3389/fphar.2017.00895.

49. Bafor EE, McKenna J, Rowan EG, Edrada-Ebel R. Characterisation of the antiproliferative constituents and activity of Ficus exasperata (Vahl) on ovarian cancer cells -a preliminary investigation. Nat Prod Res. 2017;31(18): 2164-8. https://doi.org/10.1080/14786419.2016.1277348.

50. Santiago LA, Mayor AB. Antiproliferative and apoptotic effects of ficus pseudopalma Blanco (Moraceae) against hepatocarcinoma (hepg2). Asian J Pharm Clin Res. 2015;8(2):257-61.

51. Yap VA, Qazzaz ME, Raja VJ, Bradshaw TD, Loh HS, Sim KS, Yong KT, Low YY, Lim $\mathrm{KH}$. Fistulopsines $\mathrm{a}$ and B antiproliferative septicine-type alkaloids from Ficus fistulosa. Phytochem Lett. 2016;15:136-41. https://doi.org/10.1016/j.phytol.2015.12.007.

52. Din A, Uddin G, Hussain N, Khan I, Shad AA, Choudhary M. Bioassay-guided isolation of new antitumor agent from Ficus faveolata (wall. Ex Miq.). J Cancer Sci Ther. 2013:5:404-8. https://doi.org/10.4172/1948-5956.1000233.

53. Sathiyamoorthy J, Sudhakar N. In vitro cytotoxicity and apoptotic assay in HT-29 cell line using Ficus hispida Linn: leaves extract. Pharmacogn Mag. 2018;13(4):S756-61. https://doi.org/10.4103/pm.pm_319_17. 
54. Al-Khdhairawi AAQ, Krishnan P, Mai CW, Chung FF, Leong CO, Yong KT, Chong KW, Low YY, Kam TS, Lim KH. A Bis-benzopyrroloisoquinoline alkaloid incorporating a cyclobutane core and a chlorophenanthroindolizidine alkaloid with cytotoxic activity from Ficus fistulosa var. tengerensis. J Nat Prod. 2017;80(10):2734-40. https://doi.org/10 1021/acs.jnatprod.7b00500

55. Wangkheirakpam SD, Wadawale A, Leishangthem SS, Gurumayum JS, Laitonjam WS. Cytotoxic triterpenoids from Ficus pomifera wall. Indian J Chem. 2015;54B:676-81.

56. Nugroho AE, Akbar FF. Wiyani a and Sudarsono. Cytotoxic effect and constituent profile of alkaloid fractions from Ethanolic extract of Ficus septica Burm. f. Leaves on T47D breast Cancer cells. Asian Pac J Cancer Prev. 2015;16:7337-42. https://doi.org/10.7314/apjcp.2015.16.16.7337.

57. Ogunlaja OO, Moodley R, Singh M, Baijnath H, Jonnalagadda SB. Cytotoxic activity of the bioactive principles from Ficus burtt-davyi. J Environ Sci Health B. 2018;53(4):261-75. https://doi.org/10.1080/03601234.2017.1410385.

58. El-Rafie HM, Sleem AA. Phytochemical studies of Ficus Binnendijkii leaf extracts: fractionation and bioactivities of its petroleum ether extract. $J$ Pharmacogn Phytochem. 2016:8(10):1742-50.

59. Ahmad S, Rao H, Akhtar M, Ahmad I, Munawarr MH, lqbal Z. and Nisar-urRahman. Phytochemical composition and pharmacological prospectus of Ficus bengalensis Linn. (Moraceae)- a review. J Med Plant Res. 2011;5(28): 6393-400. https://doi.org/10.5897/JMPR11.455.

60. González-Castañeda N, Cornejo-Tenorio G, Ibarra-Manríquez G. El género Ficus (Moraceae) en la provincia biogeográfica de la depresión del balsas. México Bol Soc Bot Méx. 2010;87:105-24.

61. Ibarra-Manríquez G, Cornejo-Tenorio G, González-Castañeda N, PiedraMalagón EM, Luna A. El género Ficus L. (Moraceae) en México. Bot Sci. 2012; 90:389-452.

62. Somashekhar MNN, Mahesh AR. Botanical study of four Ficus species of family Moraceae: a review. Int J Univ Pharm Bio Sci. 2013;2:558-70.

63. Wagner H, Bladt S. Plant Drug Analysis. A Thin Layer Chromatography Atlas, vol. 60. 2nd edicion ed. New York: J. Springer-Verlag Berling Heidelberg; 1997. p. 428-30

64. Bunawan H, Amin NM, Bunawan SN, Baharum SN, Mohd Noor N. Ficus deltoidea jack: A review on its phytochemical and pharmacological importance. Evid Based Complement Alternat Med. 2014;2014:902734. https://doi.org/10.1155/2014/902734.

65. Hewish MSA, Elliott R, Cunningham D, Lord CJ, Ashworth A. Cytosine-based nucleoside analogs are selectively lethal to DNA mismatch repair deficient tumour cells by enhancing levels of intracellular oxidative stress. $\mathrm{Br} J$ Cancer. 2013;108:983-92. https://doi.org/10.1038/bjc.2013.3.

66. Diana A, Franzese E, Centonze S, Carlino F, Corte CMD, Ventriglia J, Petrillo A, De Vita F, Alfano R, Ciardiello F, Orditura M. Triple-negative breast cancers: systematic review of the literature on molecular and clinical features with a focus on treatment with innovative drugs. Curr Oncol Rep. 2018;20(10):76. https://doi.org/10.1007/s11912-018-0726-6.

67. Duran-Ramírez CA, Fonseca-Juárez RM, Ibarra-Marquez G. Estudio florístico de Ficus (Moraceae) en el estado de Guerrero, México. Rev Mex Biodiversidad. 2010;81:239-62.

68. Zhang Y, Wan Y, Huo B, Li B, Jin Y, Hu X. Extracts and components of Ficus carica leaves suppress survival, cell cycle, and migration of triple-negative breast cancer MDA-MB-231 cells. Onco Targets Ther. 2018;11:4377-86. https://doi.org/10.2147/OTT.S171601.

69. Wang $S$, Wang $K$, Zhang $C$, Zhang W, Xu Q, Wang Y, Zhang Y, Li Y, Zhang $Y$, Zhu H, Song F, Lei $Y$, Bu Y. Overaccumulation of p53mediated autophagy protects against betulinic acid-induced apoptotic cell death in colorectal cancer cells. Cell Death Dis. 2017;8:e3087. https://doi.org/10.1038/cddis.2017.485.

70. Wong FC, Woo CC, Hsu A, Tan BKH. The anti-Cancer activities of Vernonia amygdalina extract in human breast cancer cell lines are mediated through caspase-dependent and p53-independent pathways. PLoS One. 2013;8(10): e78021. https://doi.org/10.1371/journal.pone.0078021.

71. Morgan CW, Julien O, Unger EK, Shah NM, Wells JA. Turning ON Caspases with genetics and small molecules. Methods Enzymol. 2014;544:179-213. https://doi.org/10.1016/B978-0-12-417158-9.00008-X.

72. Yu J, Zhang L. PUMA, a potent killer with or without p53. Oncogene. 2008; 27(Suppl 1):S71-83. https://doi.org/10.1038/onc.2009.45.

73. Vidya Priyadarsini R, Senthil Murugan R, Maitreyi S, Ramalingam K, Karunagaran D, Nagini $S$. The flavonoid quercetin induces cell cycle arrest and mitochondria-mediated apoptosis in human cervical cancer (HeLa) cells through p53 induction and NF-kappaB inhibition. Eur J Pharmacol. 2010;649 84-91. https://doi.org/10.1016/j.ejphar.2010.09.020

74. Bishayee K, Ghosh S, Mukherjee A, Sadhukhan R, Mondal J, Khuda-Bukhsh AR. Quercetin induces cytochrome-c release and ROS accumulation to promote apoptosis and arrest the cell cycle in $\mathrm{G} 2 / \mathrm{M}$, in cervical carcinoma: signal cascade and drug-DNA interaction. Cell Prolif. 2013;46:153-63. https:// doi.org/10.1111/cpr.12017.

75. Liu Y, Bi T, Wang G, Dai W, Wu G, Qian L, Gao Q, Shen G. Lupeol inhibits proliferation and induces apoptosis of human pancreatic cancer PCNA-1 cells through AKT/ERK pathways. Naunyn Schmiedeberg's Arch Pharmacol. 2015;388(3):295-304. https://doi.org/10.1007/s00210-014-1071-4.

76. Liu Y, Bi T, Dai W, Wang G, Qian L, Shen G, Gao Q. Lupeol induces apoptosis and cell cycle arrest of human osteosarcoma cells through PI3K/AKT/mTOR pathway. Technol Cancer Res Treat. 2016;15(6):NP16-24. https://doi.org/10. $1177 / 1533034615609014$

77. Liu Y, Bi T, Shen G, Li Z, Wu G, Wang Z, Qian L, Gao Q. Lupeol induces apoptosis and inhibits invasion in gallbladder carcinoma GBC-SD cells by suppression of EGFR/MMP-9 signaling pathway. Cytotechnology. 2016;68(1): 123-33. https://doi.org/10.1007/s10616-014-9763-7.

78. Min TR, Park HJ, Ha KT, Chi GY, Choi YH, Park SH. Suppression of EGFR/ STAT3 activity by lupeol contributes to the induction of the apoptosis of human non-small cell lung cancer cells. Int J Oncol. 2019;55(1):320-30. https://doi.org/10.3892/ijo.2019.4799.

79. Shen X, Cui X, Cui H, Jin Y, Jin W, Sun H. Geraniol and lupeol inhibit growth and promote apoptosis in human hepatocarcinoma cells through the MAPK signaling pathway. J Cell Biochem. 2019;120(4):5033-41. https://doi.org/10. $1002 / j c b .27779$

80. He W, Li X, Xia S. Lupeol triterpene exhibits potent antitumor effects in A427 human lung carcinoma cells via mitochondrial mediated apoptosis, ROS generation, loss of mitochondrial membrane potential and downregulation of m-TOR/PI3Ksol; AKT signalling pathway. J Buon. 2018; 23(3):635-40.

\section{Publisher's Note}

Springer Nature remains neutral with regard to jurisdictional claims in published maps and institutional affiliations.

Ready to submit your research? Choose BMC and benefit from:

- fast, convenient online submission

- thorough peer review by experienced researchers in your field

- rapid publication on acceptance

- support for research data, including large and complex data types

- gold Open Access which fosters wider collaboration and increased citations

- maximum visibility for your research: over $100 \mathrm{M}$ website views per year

At BMC, research is always in progress.

Learn more biomedcentral.com/submission 